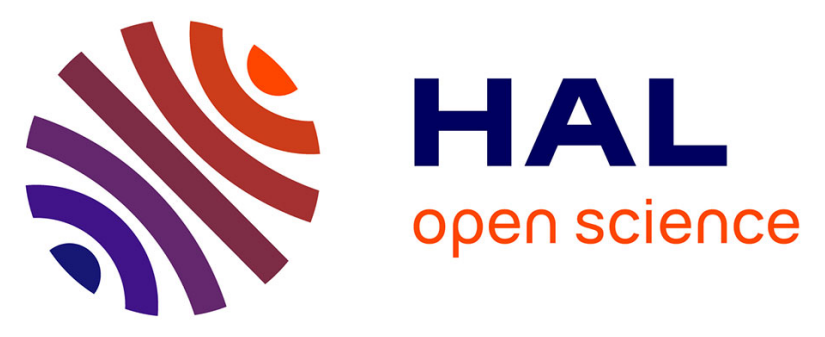

\title{
ALLELE-SPECIFIC METHYLATED MULTIPLEX REAL TIME QUANTITATIVE PCR (ASMM RTQ-PCR), A POWERFUL METHOD FOR DIAGNOSING LOSS OF IMPRINTING OF THE 11p15 REGION IN RUSSELL SILVER AND BECKWITH WIEDEMANN SYNDROMES
}

Salah Azzi, Virginie Steunou, Alexandra Rousseau, Sylvie Rossignol, Nathalie Thibaud, Fabienne Danton, Marilyne Le Jule, Christine Gicquel, Yves Le Bouc, Irene Netchine

To cite this version:

Salah Azzi, Virginie Steunou, Alexandra Rousseau, Sylvie Rossignol, Nathalie Thibaud, et al.. ALLELE-SPECIFIC METHYLATED MULTIPLEX REAL TIME QUANTITATIVE PCR (ASMM RTQ-PCR), A POWERFUL METHOD FOR DIAGNOSING LOSS OF IMPRINTING OF THE 11p15 REGION IN RUSSELL SILVER AND BECKWITH WIEDEMANN SYNDROMES. Human Mutation, 2011, 32 (2), pp.249. 10.1002/humu.21403 . hal-00612006

\section{HAL Id: hal-00612006 https://hal.science/hal-00612006}

Submitted on 28 Jul 2011

HAL is a multi-disciplinary open access archive for the deposit and dissemination of scientific research documents, whether they are published or not. The documents may come from teaching and research institutions in France or abroad, or from public or private research centers.
L'archive ouverte pluridisciplinaire HAL, est destinée au dépôt et à la diffusion de documents scientifiques de niveau recherche, publiés ou non, émanant des établissements d'enseignement et de recherche français ou étrangers, des laboratoires publics ou privés. 


\section{ALLELE-SPECIFIC METHYLATED MULTIPLEX REAL TIME QUANTITATIVE PCR (ASMM RTQ-PCR), A POWERFUL METHOD FOR DIAGNOSING LOSS OF IMPRINTING OF THE 11 15 REGION IN RUSSELL SILVER AND BECKWITH WIEDEMANN SYNDROMES}

\begin{tabular}{|c|c|}
\hline Journal: & Human Mutation \\
\hline Manuscript ID: & humu-2010-0264.R1 \\
\hline Wiley - Manuscript type: & Methods \\
\hline $\begin{array}{l}\text { Date Submitted by the } \\
\text { Author: }\end{array}$ & 13-Oct-2010 \\
\hline Complete List of Authors: & $\begin{array}{l}\text { Azzi, Salah; INSERM UMR-S 938; Université Pierre et Marie Curie, } \\
\text { Hôpital Armand Trousseau; laboratoire d'Endocrinologie } \\
\text { Moléculaire; APHP } \\
\text { Steunou, Virginie; INSERM UMR-S 938; Université Pierre et Marie } \\
\text { Curie, Hôpital Armand Trousseau; laboratoire d'Endocrinologie } \\
\text { Moléculaire } \\
\text { Rousseau, Alexandra; Hôpital Saint-Antoine-URCEST; APHP, service } \\
\text { de Pharmacologie } \\
\text { Rossignol, Sylvie; INSERM UMR-S 938; Université Pierre et Marie } \\
\text { Curie, Hôpital Armand Trousseau; Exploration Fonctionnelle } \\
\text { Endocrinienne; APHP } \\
\text { Thibaud, Nathalie; Hôpital Armand Trousseau; APHP, laboratoire } \\
\text { d'Endocrinologie Moléculaire } \\
\text { Danton, Fabienne; Hôpital Armand Trousseau; APHP, laboratoire } \\
\text { d'Endocrinologie Moléculaire } \\
\text { Le Jule, Marilyne; Hôpital Armand Trousseau; APHP, laboratoire } \\
\text { d'Endocrinologie Moléculaire } \\
\text { Gicquel, Christine; Baker IDI Heart and Diabetes Institute, } \\
\text { Epigenetics in Human Health and Disease } \\
\text { Le Bouc, Yves; INSERM UMR-S 938; Université Pierre et Marie } \\
\text { Curie, Hôpital Armand Trousseau; Exploration Fonctionnelle } \\
\text { Endocrinienne; APHP } \\
\text { Netchine, Irene; INSERM UMR-S 938; Université Pierre et Marie } \\
\text { Curie, Hôpital Armand Trousseau; Exploration Fonctionnelle } \\
\text { Endocrinienne; APHP }\end{array}$ \\
\hline Key Words: & $\begin{array}{l}\text { Imprinting molecular diagnosis, Beckwith-Wiedemann syndrome, } \\
\text { Russell-Silver syndrome, Fetal growth disorders, Imprinted } 11 \mathrm{p} 15\end{array}$ \\
\hline
\end{tabular}




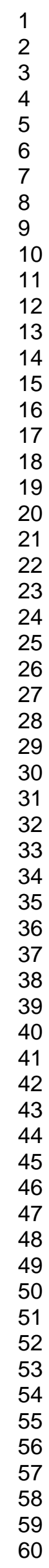

\section{SCHOLARONE ${ }^{m}$ Manuscripts}

John Wiley \& Sons, Inc. 


\title{
ALLELE-SPECIFIC METHYLATED MULTIPLEX QUANTITATIVE PCR (ASMM- QPCR), A POWERFUL METHOD FOR DIAGNOSING LOSS OF IMPRINTING OF THE 11p15 REGION IN RUSSELL SILVER AND BECKWITH WIEDEMANN SYNDROMES
}

Salah Azzi $^{1}$, Virginie Steunou ${ }^{1}$, Alexandra Rousseau ${ }^{2}$, Sylvie Rossignol ${ }^{1}$, Nathalie Thibaud $^{1}$, Fabienne Danton ${ }^{1}$, Marilyne Le Jule ${ }^{1}$, Christine Gicquel ${ }^{3}$, Yves Le Bouc ${ }^{1}$ and Irène Netchine ${ }^{1}$

${ }^{1}$ APHP, Hôpital Armand Trousseau, Laboratoire d'Explorations Fonctionnelles Endocriniennes; INSERM UMR-S938 Team 4; Université Pierre et Marie Curie-Paris 6, Paris, France; ${ }^{2}$ Hôpital Saint-Antoine-URCEST, service de Pharmacologie ; ${ }^{3}$ Epigenetics in Human Health and Disease, Baker IDI Heart and Diabetes Institute, Melbourne, Australia

\author{
Corresponding author: \\ Irène Netchine \\ Explorations Fonctionnelles Endocriniennes \\ Hôpital Armand Trousseau \\ Pierre \& Marie Curie School of Medicine \\ INSERM UMR-S938 \\ 26 Av du Dr Arnold Netter \\ 75012, France \\ Phone: +33144736448 \\ Fax: +33144736621 \\ E-mail: irene.netchine@trs.aphp.fr
}




\begin{abstract}
Many human syndromes involve a loss of imprinting (LOI) due to a loss (LOM) or a gain of methylation (GOM). Most LOI occur as mosaics and can therefore be difficult to detect with conventional methods. The human imprinted $11 \mathrm{p} 15$ region is crucial for the control of fetal growth and LOI at this locus is associated with two clinical disorders with opposite phenotypes: Beckwith-Wiedemann syndrome (BWS), characterized by fetal overgrowth and a high risk of tumors, and Russell-Silver syndrome (RSS) characterized by intrauterine and postnatal growth restriction. Until recently, we have been using Southern blotting for the diagnosis of RSS and BWS. We describe here a powerful quantitative technique, allelespecific methylated multiplex real-time quantitative PCR (ASMM RTQ-PCR), for the diagnosis of these two complex disorders. We first checked the specificity of the probes and primers used for ASMM RTQ-PCR. We then carried out statistical validation for this method, on both retrospective and prospective populations of patients. This analysis demonstrated that ASMM RTQ-PCR is more sensitive than Southern blotting for detecting low degree of LOI. Moreover, ASMM RTQ-PCR is a very rapid, reliable, simple, safe and cost effective method.
\end{abstract}

Key Words: Imprinting disorders, Beckwith-Wiedemann syndrome, Russell-Silver syndrome, 11p15 region, H19/IGF2 ICR1 11p15 locus, KCNQ1/CDKN1C ICR2 11p15 locus, methylation status analysis. 


\section{Introduction}

Genomic imprinting is an epigenetic mechanism by which a subset of mammalian genes are regulated. Imprinted genes are organized into clusters throughout the genome and are commonly regulated by an imprinting center region (ICR) (Edwards and Ferguson-Smith, 2007; Smith, et al., 2003). ICRs undergo parent-specific methylation on the cytosine residues of $\mathrm{CpG}$ dinucleotides during gametogenesis. This differential methylation regulates the allelespecific expression of several genes in the cluster (Morgan, et al., 2005; Reik, et al., 2003). A loss of imprinting (LOI) of such genes, through a gain (GOM) or a loss of DNA methylation (LOM), has been implicated in many human diseases and cancer (Robertson, 2005).

Human chromosome 11p15 encompasses two imprinted domains playing an important role in controlling fetal and postnatal growth. Each domain is differentially methylated and regulated by its own ICR [ICR1 which is paternally methylated, located in the telomeric region and regulates the H19/IGF2 domain (OMIM: 103280/147470, respectively); ICR2 which is maternally methylated, located in the centromeric region and regulates the $K C N Q 1 / C D K N 1 C$ domain (OMIM: 607542/600856, respectively)]. LOI in these two domains has been implicated in two clinical growth disorders with opposite phenotypes. LOM at ICR1 is found in more than $50 \%$ of patients with Russell-Silver Syndrome (RSS) (Gicquel, et al., 2005; Netchine, et al., 2007), whereas a GOM at ICR1 is found in $10 \%$ of patients with Beckwith Wiedemann syndrome (BWS) (Gaston, et al., 2001; Reik, et al., 1995). Abnormal DNA methylation (LOM) at ICR2 is only involved in BWS (60\% of BWS cases) (Figure 1) (Gaston, et al., 2001; Reik, et al., 1995).

BWS (OMIM 130650) is characterized by pre- and postnatal overgrowth, macroglossia, abnormal wall defects, hemihyperplasia and an increased risk of childhood tumors (Cooper, et 
al., 2005; Gaston, et al., 2001; Schneid, et al., 1993). By contrast, RSS (OMIM 180860) is a syndrome firstly described by Silver et al. (Silver, et al., 1953) and Russell (Russell, 1954). It is characterized by pre- and postnatal growth retardation, a prominent forehead, relative macrocephaly, body asymmetry and feeding difficulties and/or a body mass index $<-2$ SDS (Netchine, et al., 2007).

Our center has, for many years, been the national reference center for the molecular diagnosis and the clinical follow up of both RSS and BWS. The method we have been using for the diagnosis of RSS and BWS at our center is based on Southern blotting with methylationsensitive enzymes, for the detection of methylation abnormalities of ICR1 and ICR2 11p15 region (Gaston, et al., 2001; Netchine, et al., 2007; Schneid, et al., 1993). This technique is effective, but is time-consuming, requires large amounts of DNA and radioactivity $\left(\alpha{ }^{32} \mathrm{P}\right.$ CTP) and involves many different steps that might introduce technical problems. Furthermore, the procedures involved take a long time and the results of the test are obtained in about 15 days.

Several other methods of DNA methylation analysis have been assessed as possible replacements for Southern blotting (Fraga and Esteller, 2002). Sodium bisulfite DNA treatment followed by sequencing is one method providing detailed information about all the CpGs in a region of interest. This method generally requires cloning and transfection of bacteria that might entailing risks of contamination and false positives, and is also very timeconsuming. Another alternative to this technique is pyrosequencing, which is also based on sodium bisulfite treatment of the DNA, but without the need for cloning. This technique has the advantage of being quantitative and providing information about the methylation status of each CpG in the sequence studied. Methyl-sensitive PCR has been used by several groups to study the differential methylation status of imprinted regions after sodium bisulfite DNA 
treatment. The fact that this technique uses one common primer and two others specific to each allele may introduce amplification bias of the methylated and unmethylated allele affecting thereby the methylation index (MI) calculation. Other quantitative techniques, based on real-time PCR, have recently been developed for detecting and quantifying changes in DNA methylation within the genome, particularly in the context of cancer (Cottrell, et al., 2004; Eads, et al., 2000; Khulan, et al., 2006; Thomassin, et al., 2004; Trinh, et al., 2001; Zeschnigk, et al., 2004) and for the diagnosis of Angelman Syndrome, RSS and BWS (Alders, et al., 2009; Bruce, et al., 2008; Coffee, et al., 2006; Nazlican, et al., 2004; Priolo, et al., 2008; Wojdacz, et al., 2008; Zeschnigk, et al., 2008). One of these techniques is methylationspecific multiplex ligation-dependent probe amplification (MS-MLPA) (Eggermann, et al., 2008; Priolo, et al., 2008; Scott, et al., 2008). This technique, developed for the diagnosis of RSS and BWS, can be used to analyze the methylation status of ICR1 and ICR2 on 11p15 simultaneously, in the same assay. In addition, this technique offers the possibility to analyze copy number variations at the $11 \mathrm{p} 15$ region if the probes interrogate the abnormal region.

We describe here a powerful technique — allele-specific methylated multiplex real-time quantitative PCR (ASMM RTQ-PCR) - providing results more rapidly than Southern blotting for investigating $11 \mathrm{p} 15$ methylation status for the diagnosis of RSS and BWS. We validated this technique by comparing the methylation indexes (MI) obtained by Southern blotting and ASMM RTQ-PCR in a control population and then carried out retrospective and prospective analyses of populations of patients. We also compared the MI obtained with ASMM RTQ-PCR, Southern blotting or MS-MLPA for patients from the prospective population for whom we had sufficient DNA amount.

\section{Materials and methods}


The study was conducted in accordance with national ethics regulations (authorization numbers 681 and 682, Assistance Publique-Hôpitaux de Paris). Informed consent for genetic analysis was obtained from patients or their parents and for the control individuals.

\section{Controls}

We used ASMM RTQ-PCR and Southern blotting to analyze the methylation status of ICR1 and ICR2 on $11 \mathrm{p} 15$ in 64 healthy individuals. Among them, 50 control subjects for whom DNA was in sufficient quantity were also analyzed by MS-MPLA.

\section{Patients}

We first studied two groups of patients (RSS and BWS patients) that had previously been characterized clinically and molecularly. For the BWS group, all available samples $(n=99)$ collected between 2003 and 2005 from patients presenting all the clinical features of BWS were eligible. For RSS, 50 samples from a previously published series of 58 RSS patients were still available (Netchine, et al., 2007) and were included in this study. Methylation analysis was assessed blind to the molecular diagnosis previously obtained by Southern blotting.

We then studied a prospective cohort $(n=82)$ consisting of all the DNA samples from patients referred to our laboratory for molecular diagnosis of RSS or BWS, over a period of nine months [May 2007 - January 2008]. Methylation index (MI) was determined independently of the clinical data available for each case. Subsequently, 69 among them, for whom DNA was still available, were analyzed also by MS-MLPA.

\section{Southern blotting analysis}

We used methylation-sensitive Southern blotting to analyze the methylation status of ICR2, and of ICR1 in the 11p15 region, as previously described (Gaston, et al., 2001; Gicquel, et al., 
2005; Rossignol, et al., 2006). MI was calculated as follows [MI = amount of methylated allele x 100/ (amount of methylated + unmethylated alleles)], with Excel software.

\section{Sodium bisulfite DNA treatment}

Sodium bisulfite DNA treatment converts all the unmethylated cytosine residues in $\mathrm{CpG}$ dinucleotides to thymidine residues. The methylated cytosine residues are unaffected. This process thus generates $\mathrm{C} / \mathrm{T}$ polymorphisms, which can be used to distinguish between the methylated and the unmethylated allele. Genomic DNA $(1 \mu \mathrm{g})$ was treated with sodium bisulfite, with the EZ DNA Methylation kit (Zymo Research, Orange, CA), according to the manufacturer's instructions. It was then eluted with $50 \mu 1$ RNase-free $\mathrm{H}_{2} \mathrm{O}$.

TaqMan Allele-Specific Methylated Multiplex Real-Time Quantitative PCR (ASMM RTQPCR)

Design of probes and primers

Probes and primers were designed based on sequences with the following accession numbers from GenBank: NW 001838018.2 for ICR2 and AF125183 for ICR1 CTCF binding site 2 (CBS2) (Figure2). These two sequences encompass the NotI and SmaI sites, respectively, analyzed in the Southern blotting method. Probes and primers were designed with Primer Express version 3.0 (Applied Biosystems, France). We have designed two TaqMan minor groove-binder (MGB) probes (TaqMan-MGB probes) specifically recognizing the methylated and unmethylated alleles. The primers were designed to recognize both alleles, without discrimination. We avoided the inclusion of $\mathrm{CpG}$ dinucleotides in the primer sequences as far as possible to ensure that the methylated and unmethylated alleles were amplified equally efficiently. Our TaqMan-MGB probes contained at least two C/T nucleotides, to ensure high stringency, so that the hybridization of probes to each allele was very specific. The probes 


\section{Principle underlying ASMM RTQ-PCR}

The ASMM RTQ-PCR is based on the allele discrimination technology used for SNP genotyping and absolute TaqMan probe quantification from standard curves, a method commonly used to quantify gene expression. Following the treatment of the DNA with sodium bisulfite, a $\mathrm{C} / \mathrm{T}$ polymorphism is generated in the native $\mathrm{CpG}$, depending on the methylation status of the cytosine residue. Discrimination between the two alleles is based on the use of two probes specifically recognizing the methylated allele (containing the "C" residue) or the unmethylated allele (containing the " $T$ " residue). One of the conditions for TaqMan probe-based amplification is that the melting temperature $(\mathrm{Tm})$ of the probe must be at least $10^{\circ} \mathrm{C}$ higher than that of the primers, ensuring that the probes hybridize to the target sequence before the primers. However, sodium bisulfite treatment decreases DNA sequence stringency, limiting thereby the design of appropriate probes and primers respecting this requirement. The addition of the MGB molecule at the 3' end of the probe increases the Tm of the probe, permitting thereby to shorten its sequence. By designing TaqMan-MGB probes, we have thus overcome the limitations imposed by sodium bisulfite DNA treatment. At steady state (before the initiation of amplification), the reporter dye is close to the quencher dye, resulting in the extinction of reporter dye fluorescence, principally by Förster resonance energy transfer (FRET). By contrast, during primer extension (elongation step of the PCR), the DNA polymerase, via its 5'-exonuclease activity, cleaves only probes hybridized to the target sequence. Cleavage releases the reporter dye into the medium, where it becomes fluorescent following laser excitation (Figure 3). This phenomenon occurs in each cycle of the 
PCR, resulting in a gradual increase in reporter dye fluorescence. Fluorescence increases only if the target sequence is complementary to the probe and is amplified during PCR. These requirements ensure that nonspecific amplification is not detected (Figure 3). The standard curves are used to determine the amount of each allele in the sample. The fluorescence intensity of each of the fluorochromes is correlated with the amount of the corresponding allele in the DNA template. Therefore, in normal conditions, we expect to have equal amounts of the two alleles (reflecting an MI of about 50\%). However, in pathological conditions, in which imprinting is lost (LOI), there is an imbalance between the intensities of the two fluorochromes, reflecting LOM or GOM, depending on the imprinting abnormality concerned.

\section{Experimental procedures}

Briefly, multiplex amplification was performed with an ABI Prism 7900HT sequence detector (Applied Biosystems, France), on a 96-well plate. The reaction mixture in each well contained, in a reaction volume of $20 \mu 1,10 \mathrm{ng}$ of sodium bisulfite-treated genomic DNA (3 $\mu 1$ per well), $9 \mu \mathrm{l}$ TaqMan Universal Master Mix (Applied Biosystems, France), $900 \mathrm{nM}$ of each primer and $200 \mathrm{nM}$ of each TaqMan probe. Amplifications were carried out in triplicate. The amplification conditions, primers and probes are summarized in Table 1. The standard curve method was used to quantify each allele. A control DNA was used to generate the standard curve, with the following dilutions: $32 \mathrm{ng}, 10.67 \mathrm{ng}, 3.55 \mathrm{ng}, 1.19 \mathrm{ng}$ and $0.4 \mathrm{ng}$. The results were analyzed with SDS version 2.3 software (Applied Biosystems, France) and the MI [MI= amount of methylated allele $\mathrm{x}$ 100/ (amount of methylated + unmethylated alleles) was calculated with Excel software.

We used EpiTect Control DNAs (QIAgen, France) to assess the specificity and sensitivity of this technique. These DNAs have already been treated with sodium bisulfite and are totally unmethylated or methylated and ready to use. The assay was performed in triplicate, using 
methylated, unmethylated or a mixture of methylated and unmethylated EpiTect DNAs as the template, as described above. We mixed the two EpiTect DNAs in proportions giving a range of methylation corresponding to theoretical MIs of $100 \%, 75 \%, 60 \%, 50 \%, 40 \%, 25 \%$ and $0 \%$.

\section{DNA sequencing}

We checked primer specificity, by sequencing the two fragments corresponding to ICR1 CBS2 and ICR2, using the same primers as used for ASMM RTQ-PCR, the ABI PRISM Big Dye Terminator v1.1 cycle sequencing kit and an ABI 3100 Genetic Analyzer (Applied Biosystems). Sequences were analyzed with Sequence Navigator and Edit View software from ABI Prism.

\section{MS-MPLA analysis method}

Five hundred ng of DNA from 50 control subjects and 69 patients from the prospective cohort, for whom DNA was still available, were subjected to methylation status analysis using the methylation-specific multiplex ligation-dependent probe amplification (MS-MLPA) SALSA ME030B kit (MRC Holland, Amsterdam/NL) according to the manufacturer's protocol. The MIs were calculated using the recommended Coffalyser version 8.0 Directmethylation status analysis method (MRC Holland, Amsterdam/NL). The MI at both ICR1 and ICR2 were determined for each subject by the average of all MIs of target CpGs.

\section{Statistical analysis}

MIs are reported as means \pm SD. Agreement between the MI values obtained by Southern blotting and ASMMRTQ-PCR was assessed by calculating intra-class correlation coefficients (ICC) (Shrout and Fleiss, 1979) and determining the 95\% confidence interval by bootstrapping. Based on the MI values obtained for ICR1 and/or ICR2, a diagnosis of RSS or BWS was established or excluded. The acceptance or exclusion of the diagnosis was treated as a qualitative value in our statistical analysis. Agreement between the two tests, in terms of 
this qualitative result, was assessed by calculating the kappa coefficient (Cohen, 1960). Intraclass correlation coefficients and kappa coefficients indicate the degree of similarity between the results obtained with the two methods. An ICC or kappa coefficient greater than or equal to 0.9 was considered excellent.

Bland and Altman plots were generated to check that within-subject repeatability was not related to the size of the MI (Bland and Altman, 1986). Difference $\left(\mathrm{MI}_{\mathrm{ASMMRTQ}-\mathrm{PCR}}-\mathrm{MI}_{\text {Southern }}\right.$ blot $)$ against the average of $\mathrm{MI}\left(\left(\mathrm{MI}_{\mathrm{ASMMRTQ}-\mathrm{PCR}}+\mathrm{MI}_{\text {Southern blot }}\right) / 2\right)$. "Limits of agreement" is defined by the mean difference (Cohen, 1960) and the standard deviation of the difference as $\mathrm{dm} \pm \mathrm{SD}$. Descriptive analysis was carried out and a weighted kappa coefficient was calculated with the SAS V9 System (SAS Institute, Cary, NC, USA). The ICC and its 95\% CI were calculated and Bland and Altman plots were generated with R software version 2.0 ( $\mathrm{R}$ Foundation for Statistical Computing, Vienna, Austria; www.R-project.org).

\section{Results}

\section{Development of the ASMM RTQ-PCR technique}

Before analyzing the methylation status of DNA from patients and controls, we checked the specificity of primers and probes and evaluated the sensitivity of this technique.

Primer specificity

The specificity of the primers was evaluated by direct sequencing of the amplification product of CBS2 ICR1 and ICR2 of a control DNA sample with the same primers used in the ASMM RTQ-PCR experiment. The expected C/T dinucleotide polymorphisms were identified at the CpG dinucleotides for both CBS2 ICR1 and ICR2 sequences (Supp. Figure S1). These results demonstrate the high specificity of the primers and the efficacy of sodium bisulfite DNA treatment.

Efficiency, specificity and sensitivity of the ASMM RTQ-PCR 
The standard curves for the methylated and unmethylated probes were used to calculate the efficiency of the assay. The amplification efficiencies of CBS2 ICR 1 and ICR2 were $98 \%$ and $90 \%$, respectively, and the correlation coefficients $\left(\mathrm{R}^{2}\right)$ exceeded $99 \%$ for both regions. These results demonstrate the high amplification yield of our assay (Supp. Figure S2).

We checked the specificity of probe hybridization to each allele and investigated whether our technique could detect subtle differences in methylation, using EpiTech control DNAs. These control DNAs are of two types: totally unmethylated or totally methylated. The probes for quantifying the CBS2 ICR1 and ICR2 regions were highly specific, with no cross hybridization between the two alleles. The methylated EpiTect DNA is obtained enzymatically, and displays about $95 \%$ methylation, according to the manufacturer. Our results for the methylated probes for ICR2 were consistent with this value (94\%). The MIs calculated for the mixtures of EpiTech DNAs in various proportions were consistent with theoretical expectations for the two regions (Supp. Figure S3). Thus, these results demonstrate the high specificity of our probes and the high sensitivity of our assay.

\section{Clinical validation}

We have firstly validated ASMM RTQ-PCR by comparing it to our gold-standard method, Southern blotting. Since MS-MPLA is becoming increasingly used as an analytical technique for DNA methylation assessment particularly for RSS and BWS diagnosis, we secondly assessed a comparison of the three methods in the prospective analysis group of patients.

\section{Control subjects}

We first analyzed the methylation of the CBS2 ICR1 and ICR2 regions of DNA from 64 controls, by both Southern blotting and ASMM RTQ-PCR. The MIs calculated for the control subjects were normally distributed, which allowed us to calculate a mean MI and standard deviation (SD). The MIs calculated for CBS2 ICR1 and ICR2 by the two methods were concordant (Figure $4 \mathrm{~A}$ and B). The intra- and inter-assay coefficients were calculated for 
ASMM RTQ-PCR, and both were found to be $6 \%$ (data not shown). We considered a MI to be normal if it was within two standard deviations of the mean MI value for control subjects, and abnormal if it was outside this range (Figure $4 \mathrm{~B}$ ).

\section{Patients}

In the retrospective study, the patients were analyzed by ASMM RTQ-PCR, blind to the molecular diagnosis previously obtained by Southern blotting. In the prospective study, the patients were analyzed by both methods, blind to the clinical data. An example of the amplification curves of control subjects and patients with LOM at CBS2 ICR1 or ICR2 is shown in supplementary data (Supp. Figure S2).

\section{Clinical application}

\section{Retrospective RSS population}

In the 50 identified cases of RSS, the mean MI of CBS2 ICR1 assessed by ASMM RTQ-PCR was $28 \pm 20$ and that assessed by Southern blotting was $32 \pm 17$. The ICC was 0.89 [0.84-0.92] (Supp. Figure S4A). For the qualitative results, 62\% of samples showed LOM by both techniques, indicating maximal levels of agreement (kappa=1; Supp. Table S1).

\section{Retrospective BWS population}

The mean MI of CBS2 ICR1 was $60 \pm 13$ by ASMMRTQ-PCR and $58 \pm 12$ by Southern blotting. The agreement between the two MI measurements was 0.98 [0.97 - 0.99] (Supp. Figure S4B). All normal results and all gains of DNA methylation identified by Southern blotting were also identified by ASMM RTQ-PCR, giving an agreement of 0.91 [0.82 - 1]. Three cases identified as LOM by Southern blotting were identified as normal by ASMM RTQ-PCR (Supp. Table S2). These three patients all had a borderline MI (46\%) on Southern 
blots, the lower limit being $48 \%$. ICR1 LOM is not a molecular defect identified in BWS. Indeed, two of these patients had LOM at ICR2, while the third one had no ICR2 LOM.

The mean MI for ICR2 was $22 \pm 21$ by ASMMRTQ-PCR and $23 \pm 20$ by Southern blotting. Agreement between the two MI measurements was 0.98 [0.97 - 0.98] (Supp. Figure S4C). No divergence between the two techniques was observed for qualitative results. Both identified $64 \%$ of samples as LOM and 36\% as displaying normal DNA methylation (kappa=1; Supp. Table S3).

\section{Prospective population}

The MI values for CBS2 ICR1 and ICR2 are presented in Table 2.

\section{CBS2 ICR1 11p15}

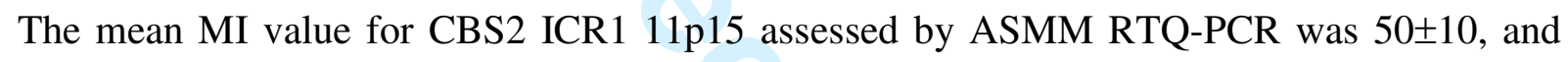
that assessed by Southern blotting was $54 \pm 8$. The quantitative agreement coefficient was 0.78 [0.59 - 0.86]. A Bland and Altman plot was generated to investigate the variation between individuals (Figure 5A). We identified four extreme points resulting in a positive slope for the overall plot, indicative of a proportional error. The MI value obtained by Southern blotting was systematically higher than the value obtained by ASMM RTQ-PCR.

Three disagreements concerning the qualitative result were identified (Table 3): two GOMs and one LOM identified by Southern blotting were identified as normal by ASMM RTQPCR. The kappa coefficient was good, but not excellent, at 0.82 [0.63 - 1].

ICR2 11p15

The mean MI value for ICR2 11 p15 was $42 \pm 14$ when assessed by ASMM RTQ-PCR and $42 \pm 13$ when assessed by Southern blotting. Quantitative agreement was excellent (ICC=0.96 [0.92 - 0.98]). Bland and Altman plots showed that most of the differences lay within the confidence interval of the difference, with the exception of three points (Figure 5B). 
Two disagreements in qualitative results were identified (Table 4). Two cases identified as normal on Southern blotting were identified as abnormal by ASMM RTQ-PCR (both LOM). One patient was a RSS patient with multilocus LOM and the other had BWS with clinical characteristics concordant with ICR2 LOM. Despite these two disagreements, the kappa coefficient was good, at $0.89[0.75-1]$.

\section{MS-MLPA analysis results}

We analyzed the methylation status of ICR1 and ICR2 11p15 region for 50 control subjects and 69 patients from the prospective population for whom DNA was still available. The mean and SD calculated from the control population were $55 \pm 3 \%$ (range $49-61 \%$ ) and $60 \pm 4 \%$ (range 52-68\%) for ICR1 and ICR2, respectively. This range is larger than that obtained by ASMM RTQ-PCR and Southern blotting (Supp. Figure S5). According to these ranges, the diagnosis established with MS-MPLA is concordant in $80 \%$ of the cases $(55 / 69)$ with that established by ASMM RTQ-PCR and Southern blotting; whereas in 20\% of the cases $(14 / 69)$ there is a discordance between the three methods (Supp. Table S4). However, for $71 \%$ of the discordant patients (10/14), MIs obtained by MS-MLPA were discordant with those of ASMM RTQ-PCR and Southern blotting. Almost all the discordant abnormal MIs obtained with MS-MLPA were represented by GOM at ICR1 $(n=5)$ or at ICR2 $(n=3)$; only 2 slight LOM were observed at both ICR1 and ICR2. Strikingly, one RSS patient and one BWS patient with respectively LOM and GOM at ICR1 11p15 with ASMM RTQ-PCR and Southern blotting had a normal MI with MS-MLPA (Supp. Table S4). These results demonstrated that MS-MLPA results can be discordant with both ASMM RTQ-PCR and Southern blotting results.

\section{Discussion}




\begin{abstract}
We have developed a technique for analysis of the methylation of CBS2 ICR1 and ICR2 in the $11 \mathrm{p} 15$ region, for the molecular diagnosis of RSS and BWS. We first validated the primers and probes used, and then studied a large cohort of patients (given that both these conditions are rare) and control subjects, by both Southern blotting and ASMM RTQ-PCR. Since the MS-MPLA is also used for RSS and BWS diagnosis, we secondly assessed with this method a sub-group of the patients analyzed in the prospective analysis to allow a comparison between the three methods.
\end{abstract}

Human ICR1 in the $11 \mathrm{p} 15$ region contains seven CTCF binding sites (CBS) within two repetitive sequences and displays a high degree of sequence identity (Frevel, et al., 1999). This makes it difficult to design primers and probes specific for the CBS to be analyzed (CBS2). For consistency with the analysis of $11 \mathrm{p} 15$ region methylation by Southern blotting, we designed probes for ASMM RTQ-PCR containing the restriction sites (Netchine, et al., 2007; Rossignol, et al., 2006) used over many years in the diagnosis of RSS and BWS by Southern blotting (Figure 2). Direct sequencing of the amplification products and the EpiTech control DNAs demonstrate that our primers and probes were highly specific to the regions of interest, CBS2 ICR1 and ICR2, with no cross hybridization observed in the multiplex amplification assay. Using the EpiTech control DNAs, we also demonstrated ASMM RTQPCR to be a highly robust and sensitive assay. Methylation abnormalities generally occur as mosaics (Gaston, et al., 2001; Gicquel, et al., 2005; Nazlican, et al., 2004; Netchine, et al., 2007; Schneid, et al., 1992; Schneid, et al., 1993), making it very difficult to identify patients with low degree of LOI. Our results indicate that the risk of false positives is lower with ASMM RTQ-PCR than with Southern blotting. Moreover, the high sensitivity of this assay increases the likelihood of identifying patients with low degree of LOI. We validated our technique by comparing the MIs of control subjects calculated by Southern blotting (goldstandard method) and by ASMM RTQ-PCR. The MI values were normally distributed, which 
allowed to calculate the mean and SD for normal MIs. We then carried out retrospective and prospective analyses on cohorts of patients, for further validation. We observed strong agreement between the two methods, showing that ASMM RTQ-PCR is as powerful technique as Southern blotting for methylation studies and for the diagnosis of RSS and BWS. For some patients, discordance between the MIs obtained for CBS2 ICR1 with the two methods was observed, in both retrospective and prospective populations. The MIs of these patients were borderline on Southern blots. The analysis of the methylation status at CBS3 ICR1 by ASMM RTQ-PCR revealed a normal MI in agreement with those obtained at CBS2 ICR1; this allowed us to make definitive diagnosis conclusion (data not shown). We also identified two patients with LOM at ICR2 by ASMM RTQ-PCR, who were considered normal on Southern blotting, in the prospective study. One of these patients was an RSS patient exhibiting multilocus imprinting defect [published elsewhere (Azzi, et al., 2009)] and the other presented clinical features of BWS consistent with ICR2 LOM. When considering the qualitative results obtained for molecular diagnosis by the two methods, the concordance was excellent in the retrospective population and good in the prospective population. However, when we consider the quantitative results obtained by calculating the MI for the two methods, the ICC obtained was smaller for CBS2 ICR1. The small discrepancy between the two methods may be accounted for by differences in the characteristics of the two methods. Southern blotting is a quantitative method requiring the hybridization of a radiolabeled probe to digested DNA transferred onto a membrane. This hybridization may generate a background signal, decreasing the accuracy of the signal intensities obtained when the bands are scanned and thus affecting MI calculation. By contrast, the ASMM RTQ-PCR is based on the quantification of fluorescence from the reporter dye after primer elongation. This fluorescence is normalized with respect to a reference dye (ROX) in the reagent mixture, the fluorescence 
intensity of which does not change during the PCR. The MIs calculated with the ASMM RTQ-PCR method are therefore more accurate.

Several other valuable methods have been developed for methylation analysis. Some of these methods are based on sodium bisulfite DNA treatment followed by subcloning and sequencing or quantitative amplification. These methods, although allowing the analysis of all CpGs between the primers, remain laborious and are not free from contamination risks (Fraga and Esteller, 2002). Another alternative to this method is pyrosequencing, which does not require subcloning, being based instead on the direct sequencing of amplification products. This technique provides quantitative information about methylation at each $\mathrm{CpG}$ in the sequence of interest and is therefore potentially promising. However, it remains expensive and is not yet available for diagnostic purposes in many institutions. Other methods based on sodium bisulfite DNA treatment and quantitative amplification require efficiency optimization (Cottrell, et al., 2004; Thomassin, et al., 2004) and some are limited to analysis of the methylation status of only one allele at a time and, therefore, cannot provide accurate information (Eads, et al., 2000; Trinh, et al., 2001). Coffee et al. have developed a TaqMan MSP method based on quantitative PCR using Light-Cycler technology, for the molecular diagnosis of RSS and BWS. The principle underlying their method is similar to that underlying ours, but the CBS6 ICR1 probes also hybridize to sites other than CBS6 in the ICR1 11p15 region. CBS6 harbors a frequent SNP (about 50\%) rs10732516 (NT_009237.17:g.808447G>A) that might affect the interpretation of the results (Figure 2). Moreover, Coffee et al. obtained a very large normal range of MIs for both CBS6 ICR1 and ICR2 (33-65\% for CBS6 ICR1 and 40-64\% for ICR2) (Coffee, et al., 2006). Our ASMM RTQ-PCR method was validated on a large cohort of control subjects and the MIs calculated were more accurate, as the calculated SDs were much smaller than those obtained by Coffee et al. [3\% in our assay rather than 6\% (ICR2) and 8\% (ICR1) for 1 SD in Coffee's assay]. 
QiaGen has been developed some TaqMan assays to study the methylation status of promoters of certain genes involved in cancer. The principle of their assays is substantially the same as our since they use two allele-specific probes to quantify the methylated and the unmethylated alleles. Our assay assesses the methylation study of imprinted loci for which the methylation status is balance between the parental alleles. By contrast, QiaGen's assays are developed to study the methylation changes of non imprinted promoters. The methylation of such regions could be different between CpGs and could hinder the hybridization of the probes which could introduce an error of MI calculation. The MI is calculated using the ratio of the cycle threshold $\left(\mathrm{C}_{\mathrm{T}}\right)$ of the methylated and unmethylated allele in the same sample. To be more accurate, this calculation requires the use of a control probe in the same assay so that to normalize the DNA amount. We used the standard curve to determine the MI. This method of calculation (standard curve) does not need the use of a control probe for normalization, since the quantity of each allele is calculated by the standard curves. For the diagnosis of RSS and BWS, Wojdacz et al and Alders et al (Alders, et al., 2009; Wojdacz, et al., 2008) have recently developed a methylation-sensitive high-resolution melting (MS-HRM) method for the methylation analysis of the $H 19$ promoter. Although this method is reliable, it is however difficult to identify low degree of LOI present in pUPD11, 11p duplications and 11p15 epimutation as these abnormalities are frequently in mosaics.

Some other methods based on the use of methylation-sensitive restriction enzymes have also been developed for methylation analyses. These methods focus on a single $\mathrm{CpG}$, and may therefore fail to detect certain individuals with low degree of LOI, necessitating additional testing on proximal regions (Bruce, et al., 2008). The methylation-specific multiplex ligationdependent probe amplification assay (MS-MLPA) was also developed for analysis of methylation in the 11p15 region for the diagnosis of RSS and BWS (Eggermann, et al., 2008; Priolo, et al., 2008; Scott, et al., 2008). It uses a set of probes hybridizing at ICR1 and ICR2, 
which are hybridized to the DNA and then digested with a methylation-sensitive restriction enzyme (HhaI) before amplification of the ligated probes. This method has been described as robust, reproducible and sensitive. To test this method, we have analyzed a control population and a population of patients for whom the DNA was still available and who had already been analyzed with Southern blotting and ASMM RQ-PCR. Our results showed that the range of normal MI in both ICR2 and H19DMR are larger than that obtained by Southern blotting and ASMM RTQ-PCR. These large values of normal range could be explained by variation of MIs at each CpG. In addition, 10 among 69 patients analyzed showed discordant MI with MSMLPA when comparing with the two other methods. Strikingly, we have failed to detect two patients with $11 \mathrm{p} 15$ abnormalities. Some probes of the probe mix ME030B particularly those hybridizing at H19DMR have been showed to give inappropriate MIs or copy number (Priolo, et al., 2008; Scott, et al., 2008). Since these reports, the SALSA ME030B probe mix has been changed. It should be noted that all the methyl-specific probes hybridizing to H19DMR are located in the promoter region of $H 19$ gene except one (08745-L08765) that is located between CBS6 and CBS7 (Figure 2). It is recognized that ICR1 is the imprinting centre that regulates the telomeric region of the 11 p15 region. Furthermore, uneven methylation has been previously reported at the promoter region of $H 19$ (Vu, et al., 2000) and dissociation between the methylation status and H19 promoter has been reported in RSS patients (Horike, et al., 2009). Improvements are therefore required in the SALSA ME030B probe set, together with a careful analysis and validation of the results.

ASMM RTQ-PCR is easy to perform, reproducible, robust and highly sensitive. Results can be obtained in one and half days, and the analysis is very easy to monitor. In addition, the use of real-time PCR reduces the handling errors associated with manual manipulation, by decreasing the number of laboratory steps performed in the assay. Moreover, ASMM RTQ- 
PCR is highly suitable for diagnostic purposes because it is relatively cheap and requires less than $10 \mathrm{ng}$ of sodium bisulfate-treated DNA for triplicate assays. The use of a 96-well plate makes it possible to analyze 26 patients in a single PCR. This method is the first to be validated on such a large series of controls and patients with and without 11p15 LOI.

Robust and reliable techniques are required for molecular diagnosis of these abnormal patterns of methylation occurring as mosaics. This technique is currently transferred for the diagnosis of RSS and BWS in our laboratory and substituted to Southern blotting and allows accurate diagnosis with a small DNA quantity. This is the first step to allow the development of an antenatal diagnosis for both RSS and BWS. In our experience, there is an increasing demand for BWS and RSS antenatal diagnosis to improve the obstetrical follow-up of these pregnancies and orient the medical counseling in case of severe IUGR or overgrowth syndrome during the pregnancy. Because of severe intra-uterine growth retardation, RSS fetuses are often delivered by the obstetricians before term. However, they then frequently have neonatal complication and this could be avoided if the diagnosis was known as they usually have a good tolerance to in utero gestation until term. Since the methylation anomalies of the $11 \mathrm{p} 15$ region occur in a mosaic manner, this diagnosis is very delicate in cases of low degree of LOI and mosaicism and requires a very reliable method that needs very small amount of DNA, extracted directly from the amniocytes pellet without a step of culture. ASMM RTQ-PCR technique responds to these requirements and will make possible to develop such a diagnosis. Furthermore, ASMM RTQ-PCR could be adapted for studies of methylation status at other imprinted loci involved in human syndromes and has been used for the evaluation of seven other imprinted loci as part of a multilocus study on our cohort of RSS and BWS patients with LOI at 11p15 (Azzi, et al., 2009). It could potentially be used as a starting point for the design of assays for postnatal as well as antenatal diagnosis for PraderWilli syndrome, Angelmann syndrome, transient neonatal diabetes mellitus, chromosome 14 


\section{ACKNOWLEDGEMENTS}

We thank the patients and their families and the physicians for patients' referrals and collection of the clinical data.

\section{Reference}

Alders M, Bliek J, vd Lip K, vd Bogaard R, Mannens M. 2009. Determination of KCNQ1OT1 and H19 methylation levels in BWS and SRS patients using methylationsensitive high-resolution melting analysis. Eur J Hum Genet 17(4):467-73.

Azzi S, Rossignol S, Steunou V, Sas T, Thibaud N, Danton F, Le Jule M, Heinrichs C, Cabrol S, Gicquel C and others. 2009. Multilocus methylation analysis in a large cohort of 11p15-related foetal growth disorders (Russell Silver and Beckwith Wiedemann syndromes) reveals simultaneous loss of methylation at paternal and maternal imprinted loci. Hum Mol Genet 18(24):4724-33.

Bland JM, Altman DG. 1986. Statistical methods for assessing agreement between two methods of clinical measurement. Lancet 1(8476):307-10.

Bruce S, Hannula-Jouppi K, Lindgren CM, Lipsanen-Nyman M, Kere J. 2008. Restriction site-specific methylation studies of imprinted genes with quantitative real-time PCR. Clin Chem 54(3):491-9.

Coffee B, Muralidharan K, Highsmith WE, Jr., Lapunzina P, Warren ST. 2006. Molecular diagnosis of Beckwith-Wiedemann syndrome using quantitative methylation-sensitive polymerase chain reaction. Genet Med 8(10):628-34. 
Cohen J. 1960. A coefficient of agreement for nominal scales. . Educ. Psychol. Meas. 20:3746.

Cooper WN, Luharia A, Evans GA, Raza H, Haire AC, Grundy R, Bowdin SC, Riccio A, Sebastio G, Bliek J and others. 2005. Molecular subtypes and phenotypic expression of Beckwith-Wiedemann syndrome. Eur J Hum Genet 13(9):1025-32.

Cottrell SE, Distler J, Goodman NS, Mooney SH, Kluth A, Olek A, Schwope I, Tetzner R, Ziebarth H, Berlin K. 2004. A real-time PCR assay for DNA-methylation using methylation-specific blockers. Nucleic Acids Res 32(1):e10.

Eads CA, Danenberg KD, Kawakami K, Saltz LB, Blake C, Shibata D, Danenberg PV, Laird PW. 2000. MethyLight: a high-throughput assay to measure DNA methylation. Nucleic Acids Res 28(8):E32.

Edwards CA, Ferguson-Smith AC. 2007. Mechanisms regulating imprinted genes in clusters. Curr Opin Cell Biol 19(3):281-9.

Eggermann T, Schonherr N, Eggermann K, Buiting K, Ranke MB, Wollmann HA, Binder G. 2008. Use of multiplex ligation-dependent probe amplification increases the detection rate for 11p15 epigenetic alterations in Silver-Russell syndrome. Clin Genet 73(1):7984.

Fraga MF, Esteller M. 2002. DNA methylation: a profile of methods and applications. Biotechniques 33(3):632, 634, 636-49.

Frevel MA, Sowerby SJ, Petersen GB, Reeve AE. 1999. Methylation sequencing analysis refines the region of H19 epimutation in Wilms tumor. J Biol Chem 274(41):2933140.

Gaston V, Le Bouc Y, Soupre V, Burglen L, Donadieu J, Oro H, Audry G, Vazquez MP, Gicquel C. 2001. Analysis of the methylation status of the KCNQ1OT and H19 genes in leukocyte DNA for the diagnosis and prognosis of Beckwith-Wiedemann syndrome. Eur J Hum Genet 9(6):409-18.

Gicquel C, Rossignol S, Cabrol S, Houang M, Steunou V, Barbu V, Danton F, Thibaud N, Le Merrer M, Burglen L and others. 2005. Epimutation of the telomeric imprinting center region on chromosome 11p15 in Silver-Russell syndrome. Nat Genet 37(9):1003-7.

Horike S, Ferreira JC, Meguro-Horike M, Choufani S, Smith AC, Shuman C, Meschino W, Chitayat D, Zackai E, Scherer SW and others. 2009. Screening of DNA methylation at the H19 promoter or the distal region of its ICR1 ensures efficient detection of chromosome 11p15 epimutations in Russell-Silver syndrome. Am J Med Genet A 149A(11):2415-23.

Khulan B, Thompson RF, Ye K, Fazzari MJ, Suzuki M, Stasiek E, Figueroa ME, Glass JL, Chen Q, Montagna C and others. 2006. Comparative isoschizomer profiling of cytosine methylation: the HELP assay. Genome Res 16(8):1046-55.

Morgan HD, Santos F, Green K, Dean W, Reik W. 2005. Epigenetic reprogramming in mammals. Hum Mol Genet 14 Spec No 1:R47-58.

Nazlican H, Zeschnigk M, Claussen U, Michel S, Boehringer S, Gillessen-Kaesbach G, Buiting K, Horsthemke B. 2004. Somatic mosaicism in patients with Angelman syndrome and an imprinting defect. Hum Mol Genet 13(21):2547-55.

Netchine I, Rossignol S, Dufourg MN, Azzi S, Rousseau A, Perin L, Houang M, Steunou V, Esteva B, Thibaud $\mathrm{N}$ and others. 2007. 11p15 imprinting center region 1 loss of methylation is a common and specific cause of typical Russell-Silver syndrome: clinical scoring system and epigenetic-phenotypic correlations. J Clin Endocrinol Metab 92(8):3148-54.

Priolo M, Sparago A, Mammi C, Cerrato F, Lagana C, Riccio A. 2008. MS-MLPA is a specific and sensitive technique for detecting all chromosome 11p15.5 imprinting defects of BWS and SRS in a single-tube experiment. Eur J Hum Genet 16(5):565-71. 
Reik W, Brown KW, Schneid H, Le Bouc Y, Bickmore W, Maher ER. 1995. Imprinting mutations in the Beckwith-Wiedemann syndrome suggested by altered imprinting pattern in the IGF2-H19 domain. Hum Mol Genet 4(12):2379-85.

Reik W, Santos F, Dean W. 2003. Mammalian epigenomics: reprogramming the genome for development and therapy. Theriogenology 59(1):21-32.

Robertson KD. 2005. DNA methylation and human disease. Nat Rev Genet 6(8):597-610.

Rossignol S, Steunou V, Chalas C, Kerjean A, Rigolet M, Viegas-Pequignot E, Jouannet P, Le Bouc Y, Gicquel C. 2006. The epigenetic imprinting defect of patients with Beckwith-Wiedemann syndrome born after assisted reproductive technology is not restricted to the 11p15 region. J Med Genet 43(12):902-7.

Russell A. 1954. A syndrome of intra-uterine dwarfism recognizable at birth with craniofacial dysostosis, disproportionately short arms, and other anomalies (5 examples). Proc R Soc Med 47(12):1040-4.

Schneid H, Seurin D, Noguiez P, Le Bouc Y. 1992. Abnormalities of insulin-like growth factor (IGF-I and IGF-II) genes in human tumor tissue. Growth Regul 2(1):45-54.

Schneid H, Seurin D, Vazquez MP, Gourmelen M, Cabrol S, Le Bouc Y. 1993. Parental allele specific methylation of the human insulin-like growth factor II gene and BeckwithWiedemann syndrome. J Med Genet 30(5):353-62.

Scott RH, Douglas J, Baskcomb L, Nygren AO, Birch JM, Cole TR, Cormier-Daire V, Eastwood DM, Garcia-Minaur S, Lupunzina P and others. 2008. Methylation-specific multiplex ligation-dependent probe amplification (MS-MLPA) robustly detects and distinguishes $11 \mathrm{p} 15$ abnormalities associated with overgrowth and growth retardation. J Med Genet 45(2):106-13.

Shrout PE, Fleiss JL. 1979. Intraclass correlations: uses in assessing rater reliability. Psychol Bull 86(2):420-8.

Silver HK, Kiyasu W, George J, Deamer WC. 1953. Syndrome of congenital hemihypertrophy, shortness of stature, and elevated urinary gonadotropins. Pediatrics 12(4):368-76.

Smith RJ, Dean W, Konfortova G, Kelsey G. 2003. Identification of novel imprinted genes in a genome-wide screen for maternal methylation. Genome Res 13(4):558-69.

Thomassin H, Kress C, Grange T. 2004. MethylQuant: a sensitive method for quantifying methylation of specific cytosines within the genome. Nucleic Acids Res 32(21):e168.

Trinh BN, Long TI, Laird PW. 2001. DNA methylation analysis by MethyLight technology. Methods 25(4):456-62.

Vu TH, Li T, Nguyen D, Nguyen BT, Yao XM, Hu JF, Hoffman AR. 2000. Symmetric and asymmetric DNA methylation in the human IGF2-H19 imprinted region. Genomics 64(2):132-43.

Wojdacz TK, Dobrovic A, Algar EM. 2008. Rapid detection of methylation change at H19 in human imprinting disorders using methylation-sensitive high-resolution melting. Hum Mutat 29(10):1255-60.

Zeschnigk M, Albrecht B, Buiting K, Kanber D, Eggermann T, Binder G, Gromoll J, Prott EC, Seland S, Horsthemke B. 2008. IGF2/H19 hypomethylation in Silver-Russell syndrome and isolated hemihypoplasia. Eur J Hum Genet 16(3):328-34.

Zeschnigk M, Bohringer S, Price EA, Onadim Z, Masshofer L, Lohmann DR. 2004. A novel real-time PCR assay for quantitative analysis of methylated alleles (QAMA): analysis of the retinoblastoma locus. Nucleic Acids Res 32(16):e125. 


\section{Figure legends:}

Figure 1: Representation of the $11 p 15$ region and its imprinting related to $11 p 15$ disorders. The middle panel represents the normal situation. The $11 \mathrm{p} 15$ region encompasses two imprinted centers, ICR1 at the telomeric domain and ICR2 at the centromeric one. ICR1 is methylated on the paternal allele, to which CTCF does not bind, thereby allowing the shared enhancers (E) access to the IGF2 promoters and stimulating their activation. The ICR1 on the maternal allele is not methylated; CTCF can therefore bind to this allele, acting as an insulator, preventing the activation of $I G F 2$ promoters by shared enhancers but permitting the 
activation of the $H 19$ promoter. ICR2 is methylated on the maternal allele where CDKN1C and $K C N Q 1$ are expressed. On the paternal non-methylated allele, KCNQ1OT1 (non coding RNA) is expressed and regulates the imprinting in cis. Two imprinting defects can lead to BWS: the first is loss of methylation (LOM) at ICR2 (upper left-hand panel) leading to the biallelic expression of $K C N Q 1 O T 1$ and a loss of expression of $C D K N 1 C$ and $K C N Q 1$. This abnormality accounts for $60 \%$ of BWS cases. The second is gain of methylation (GOM) at ICR1 (upper right-hand panel), leading to the biallelic expression of IGF2 (the main fetal growth factor) and $H 19$ (non coding RNA) downregulation. This abnormality accounts for $10 \%$ of BWS cases. In more than $50 \%$ of RSS patients, LOM at ICR 1 is involved (lower middle panel). This abnormality leads to the down regulation of $I G F 2$ and the biallelic expression of $H 19$.

Figure 2: Diagram representing the $11 p 15$ region illustrating the positions of primers and probes used in different assays. The open boxes on ICR 1 region represent the B and A repeats, the gray boxes represent the positions of the 7 CTCF binding sites (CBS). ICR2 (left gray box) is located in the 10th intron of KCNQ1 gene (hatched box). The ASMM RTQ-PCR assays, designed on CBS2 ICR1 and ICR2, are illustrated by black arrows and bares; the TaqMan MGB-probes encompass the methyl-sensitive sites, SmaI (CBS2 ICR1) and NotI (ICR2), used in Southern blotting. Coffee's assays schematized by the gray arrows and bares are designed on CBS6 ICR1 and ICR2. The positions of the restriction sites and probes used in Southern blotting for both ICR1 and ICR2 are depicted. MS-MLPA probe set is shown on the upper panel of the diagram for H19DMR and the bottom panel of the diagram for ICR2, three of the four probes interrogating H19DMR is located within H19 promoter and only one probe is located between CBS6 and CBS7. The circles indicate the CpGs sites. 
Figure 3: Principle of ASMM RTQ-PCR. The upper panel represents the sodium bisulfite DNA treatment step. The methylated cytosine residues (blue stars) at the $\mathrm{CpG}$ dinucleotide remain unchanged, whereas cytosine residues without methyl groups are converted into thymidine residues. The lower panel represents the quantitative real-time PCR step. The two probes were labeled with different fluorochromes, FAM (F) and VIC (V), and specifically recognized either the methylated or the unmethylated allele. After elongation, the probes were degraded and the two fluorochromes were released into the medium, where they became fluorescent on laser excitation. Black circles: methylated cytosines; white circles: unmethylated cytosines; NFQ: non fluorescent quencher; MGB: minor groove binder.

Figure 4: A) Histogram showing the mean MI of CBS2 ICR1 and ICR2 calculated by ASMM RTQ-PCR and Southern blotting, for a population of control subjects ( $n=64)$. The MIs in B represent the mean MI \pm SD (standard deviation). Three independent experiments were carried out. The error bars in the histograms represent $\pm 1 \mathrm{SD}$.

Figure 5: Bland and Altman's graphical representation of the intraclass correlation coefficient (ICC) and its IC95\% by bootstrap. ASMM RTQ-PCR and Southern blotting agreement in the prospective cohort for CBS2 ICR1 (A) and ICR2 (B) (difference of MI measurements against their mean value). 'Limits of agreement' is defined by the mean difference $(\mathrm{dm})$ and the standard deviation of the difference as $\mathrm{dm} \pm \mathrm{SD}$ for CBS2 ICR1 (A) and ICR2 (B). 
Table 1. Sequences of primers and probes and amplification conditions used in ASMM RTQPCR

\begin{tabular}{|c|c|c|c|c|c|}
\hline Locus & $\begin{array}{c}\text { GenBank } \\
\text { Accession } \\
\text { Number }\end{array}$ & $\begin{array}{c}\text { Primer } \\
\text { sequence }\left(5^{\prime}-3^{\prime}\right)\end{array}$ & $\begin{array}{c}\text { Probe } \\
\text { sequence }\left(5^{\prime}-3^{\prime}\right)\end{array}$ & $\begin{array}{l}\text { Amplification } \\
\text { Conditions }\end{array}$ & $\begin{array}{l}\text { Fragment } \\
\text { size (bp) }\end{array}$ \\
\hline 12 & \multirow{2}{*}{ AF125183 } & $\begin{array}{l}\text { CBS2 F: } \\
\text { GTTTTGATGGTGTAGA } \\
\text { ATTGGTTGTAG }\end{array}$ & $\begin{array}{l}\text { ICR1 CBS2 M: 6FAM- } \\
\text { TTTCGGGTTACGTAAGTT-MGB }\end{array}$ & \multirow{2}{*}{$\begin{array}{c}95^{\circ} \mathrm{C} \text { x } 10 \mathrm{~min} \\
{\left[95^{\circ} \mathrm{C} \times 30 \mathrm{~s}\right.} \\
55^{\circ} \mathrm{C} \times 30 \mathrm{~s} \\
\left.60^{\circ} \mathrm{C} \times 1 \mathrm{~min}\right] \mathrm{x} \\
50 \text { cycles }\end{array}$} & \multirow{2}{*}{184} \\
\hline $\begin{array}{l}13 \text { ICR1 } \\
14 \\
15 \\
16 \\
17\end{array}$ & & $\begin{array}{l}\text { CBS2 R: } \\
\text { TCCCATAAATATTCTA } \\
\text { TCCCTCACTACC }\end{array}$ & $\begin{array}{l}\text { ICR1 CBS2 UM: VIC- } \\
\text { AAATGTTTTGGGTTATGTAAGT- } \\
\text { MGB }\end{array}$ & & \\
\hline 18 & NW & $\begin{array}{l}\text { ICR2 F: } \\
\text { GGGTTAGTTTTTTGYG } \\
\text { TGATGTGTTT }\end{array}$ & $\begin{array}{l}\text { ICR2 M: 6FAM- } \\
\text { ATAGCGGTCGTATTTCGATAT-MGB }\end{array}$ & \multirow{2}{*}{$\begin{array}{l}95^{\circ} \mathrm{C} \times 10 \mathrm{~min} \\
{\left[95^{\circ} \mathrm{C} \times 15 \mathrm{~s}\right.} \\
\left.60^{\circ} \mathrm{C} \times 1 \mathrm{~min}\right] \times \\
50 \text { cycles }\end{array}$} & \multirow{2}{*}{117} \\
\hline $\begin{array}{ll}22^{2} \\
23 \\
24 \\
24\end{array}$ & 001838018.2 & $\begin{array}{l}\text { ICR2 R: } \\
\text { ACCTCCACACCRAAA } \\
\text { ACCCA }\end{array}$ & $\begin{array}{l}\text { ICR2 UM: VIC- } \\
\text { TGTGTGAGGATAGTGGTTGT-MGB }\end{array}$ & & \\
\hline
\end{tabular}

The CpG position before sodium bisulfite DNA treatment are underlined. 
Table 2. Mean MI and SD of CBS2 ICR1 and ICR2 calculated by ASMM RTQ-PCR and Southern blotting for all patients in the prospective study

\begin{tabular}{|l|c|c|}
\hline & ICR1 11p15 & ICR2 11p15 \\
\hline MI ASMMRTQ-PCR & $50 \pm 10$ & $42 \pm 14$ \\
\hline MI Southern blotting & $54 \pm 8$ & $42 \pm 13$ \\
\hline
\end{tabular}

Table 3. Qualitative results for CBS2 ICR1 in the prospective study

\begin{tabular}{|c|c|c|c|c|}
\hline \multicolumn{2}{|c|}{ ICR1 11p15 } & \multicolumn{2}{|c|}{$\begin{array}{l}\text { Southern blot } \\
\text { conclusion }\end{array}$} & \multirow[t]{2}{*}{ Total } \\
\hline & & $\mathbf{A}$ & $\mathbf{N}$ & \\
\hline $\begin{array}{c}\text { ASMM } \\
\text { RTQ-PCR }\end{array}$ & $\mathbf{A}$ & 8 & 0 & 8 \\
\hline Conclusion & $\mathbf{N}$ & 3 & 71 & 74 \\
\hline & Total & 11 & 71 & 82 \\
\hline
\end{tabular}

Table 4. Qualitative results for ICR2 in the prospective study

\begin{tabular}{|c|c|c|c|c|}
\hline \multirow{2}{*}{\multicolumn{2}{|c|}{ ICR2 11p15 }} & \multicolumn{2}{|c|}{$\begin{array}{l}\text { Southern blotting } \\
\text { conclusion }\end{array}$} & \multirow{2}{*}{ Total } \\
\hline & & $\mathbf{A}$ & $\mathbf{N}$ & \\
\hline $\begin{array}{l}\text { ASMM RTQ- } \\
\text { PCR }\end{array}$ & $\mathbf{A}$ & 10 & 2 & 12 \\
\hline \multirow[t]{2}{*}{ Conclusion } & $\mathbf{N}$ & 0 & 70 & 70 \\
\hline & Total & 10 & 72 & 82 \\
\hline
\end{tabular}




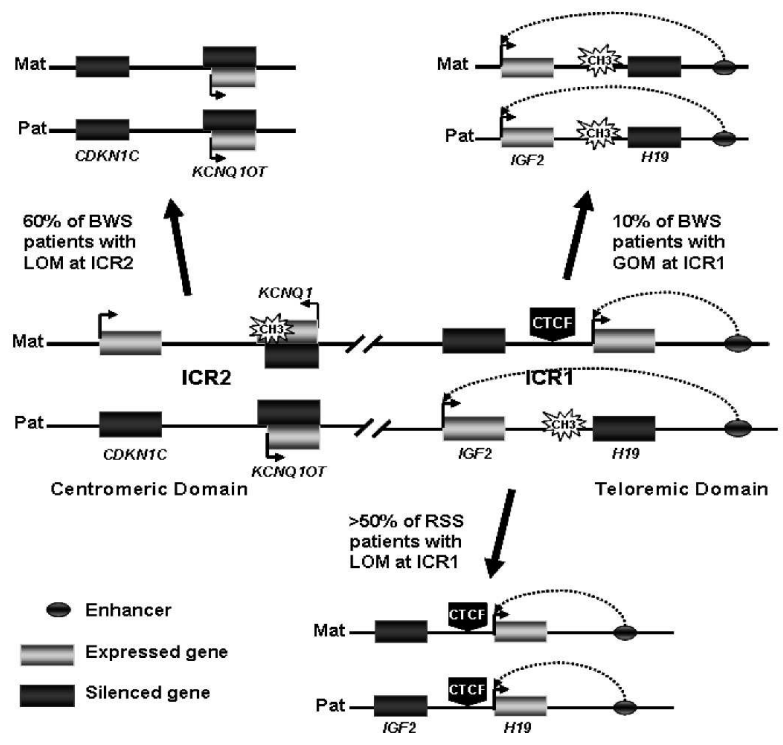

$297 \times 209 \mathrm{~mm}(300 \times 300$ DPI $)$

John Wiley \& Sons, Inc. 


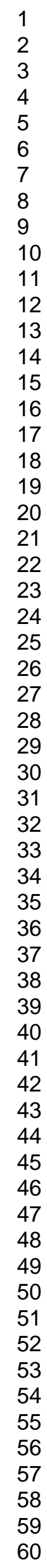

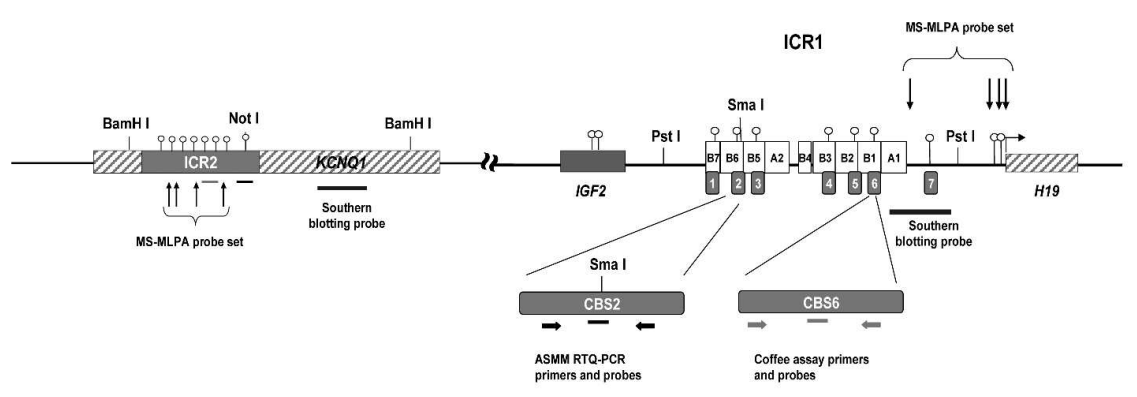

$279 \times 215 \mathrm{~mm}(300 \times 300 \mathrm{DPI})$

John Wiley \& Sons, Inc. 

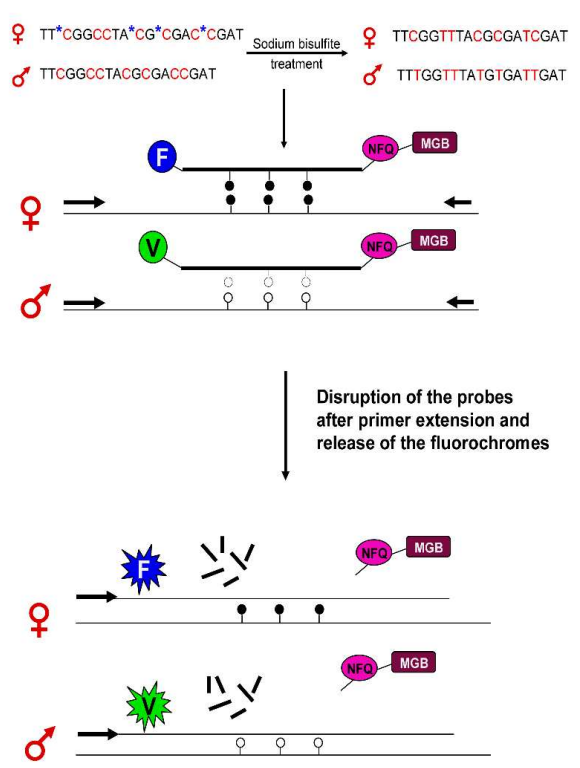

$297 \times 209 \mathrm{~mm}(300 \times 300 \mathrm{DPI})$

John Wiley \& Sons, Inc. 

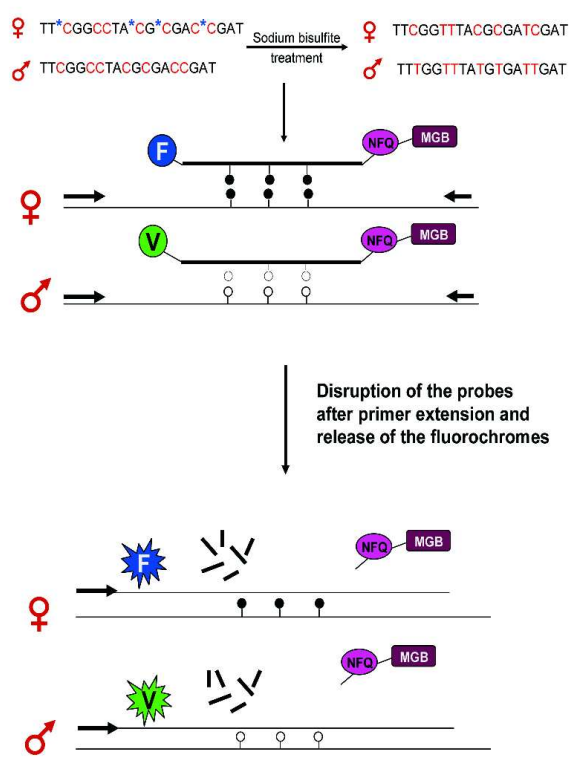

$297 \times 209 \mathrm{~mm}(300 \times 300$ DPI $)$

John Wiley \& Sons, Inc. 
A

$707 \quad$ - MI ASMMRTQ-PCR

60- घMI Southern Blot

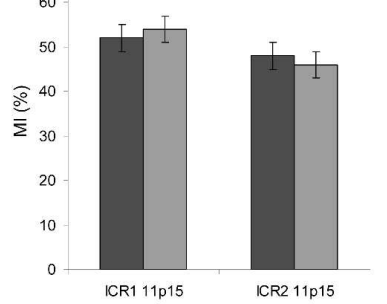

B

\begin{tabular}{|l|c|c|}
\hline Methods & ICR1 11p15 & ICR2 11p15 \\
\hline $\begin{array}{l}\text { MI ASMM RTQ-PCR } \\
(n=64)\end{array}$ & $52 \pm 3$ & $48 \pm 3$ \\
\hline $\begin{array}{l}\text { MI Southem Blot } \\
(n=64)\end{array}$ & $54 \pm 3$ & $46 \pm 3$ \\
\hline
\end{tabular}

$297 \times 209 \mathrm{~mm}(300 \times 300$ DPI)

John Wiley \& Sons, Inc. 
A

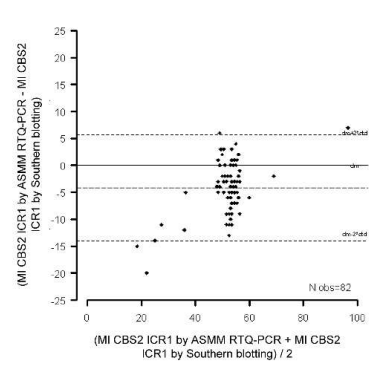

B

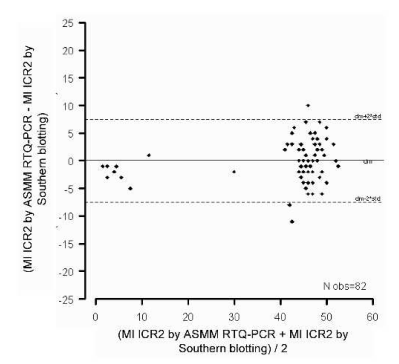

$297 \times 209 \mathrm{~mm}(300 \times 300$ DPI $)$

John Wiley \& Sons, Inc. 


\section{Supplementary Materials}

\section{Figure and legends}

A

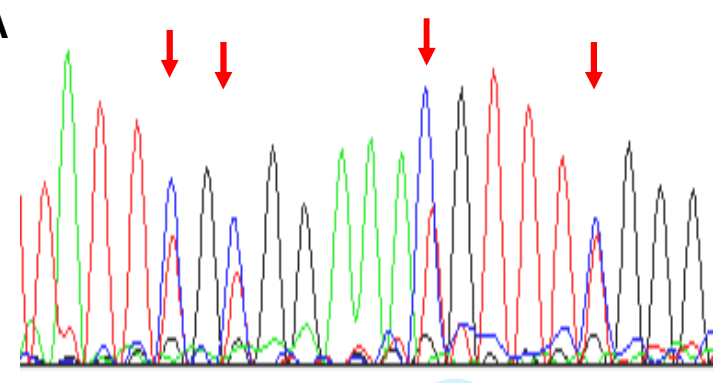

B

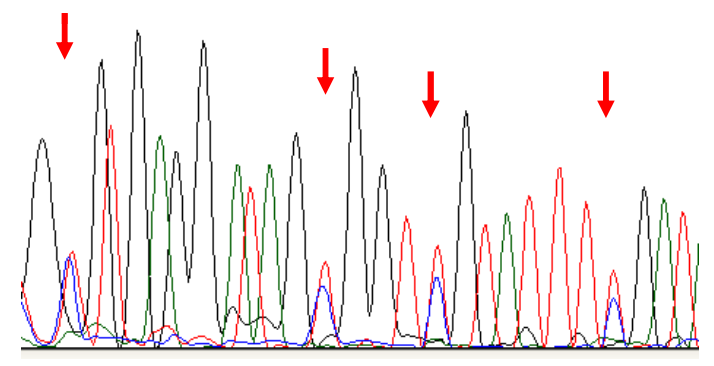

Figure S1: Electrophoregram depicting the sequences of CBS2 ICR1 (A) and ICR2 (B). The C/T polymorphisms are indicated by the arrows. 
A

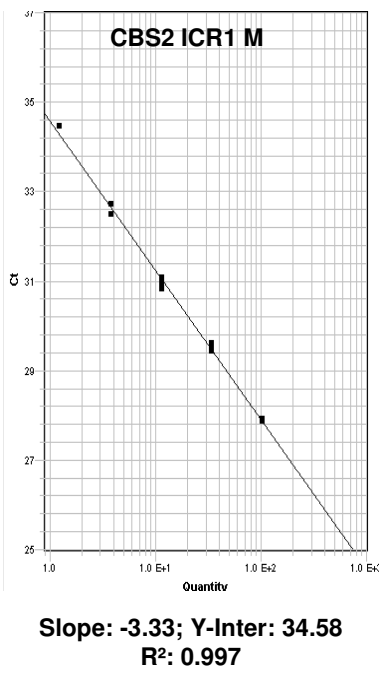

$\mathrm{B}$

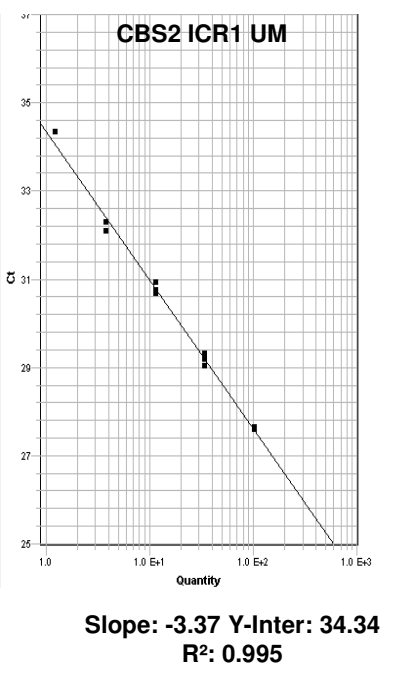

E

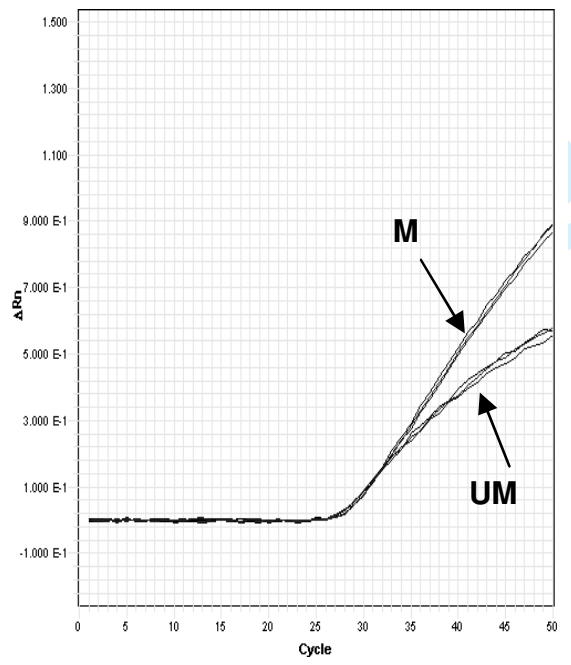

G

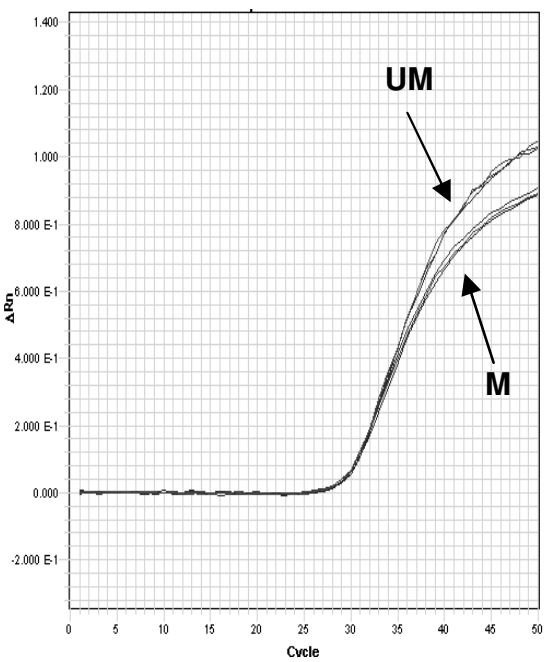

C

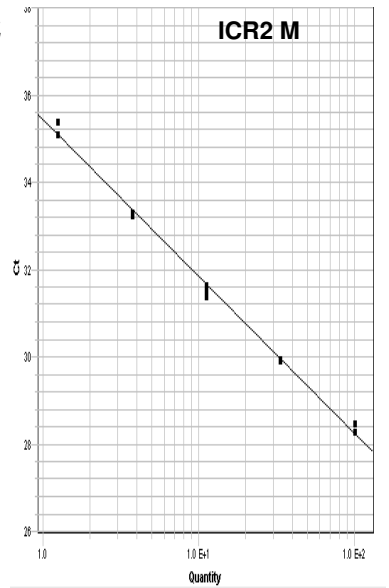

Slope: -3.58; Y-Inter: $\mathbf{3 5 . 4 2}$ $R^{2}: 0.996$

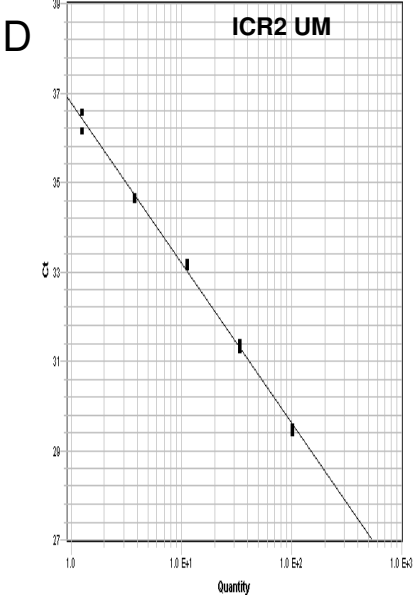

Slope: -3.58; Y-Inter: 36.88 $\mathbf{R}^{2}: 0.996$

F

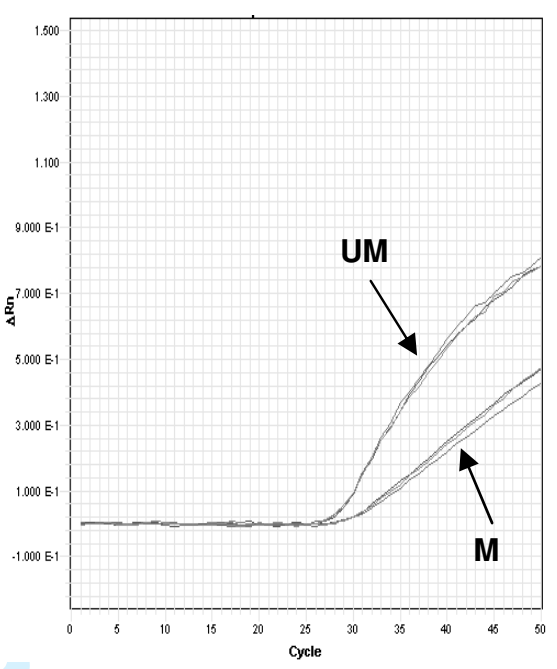

$\mathrm{H}$

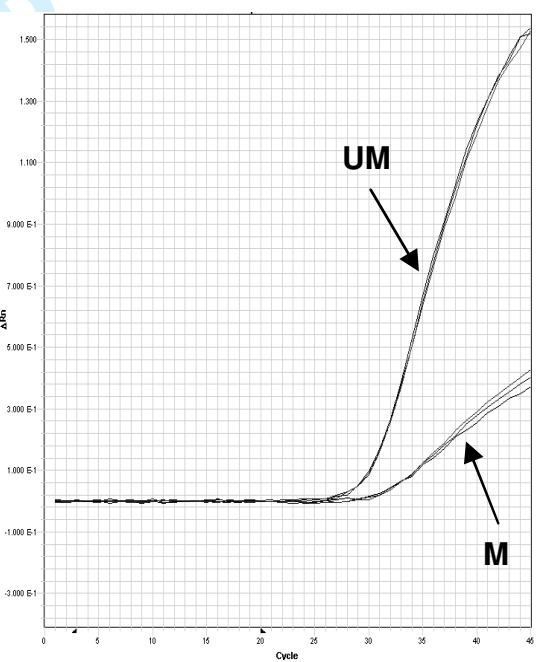

Figure S2: Standard curves for both unmethylated and methylated alleles of CBS2 ICR1 (A and B) and ICR2 (C and D). The slops and the correlation coefficients are indicated under each standard curve. The amplification efficiency calculated from the slopes was up to $98 \%$ and $90 \%$, for CBS2 ICR1 and ICR2, respectively. E-H show amplification curves for CBS2 
ICR1 (E and F) and ICR2 (G and H) for a control subject (E and G) and an RSS patient (F) or BWS patient $(\mathrm{H})$. The unmethylated and methylated curves overlap in the control situation, whereas in patients with loss of methylation at CBS2 ICR1 or ICR2, amplification of the unmethylated allele occurs several cycles earlier. M: methylated; UM: unmethylated.

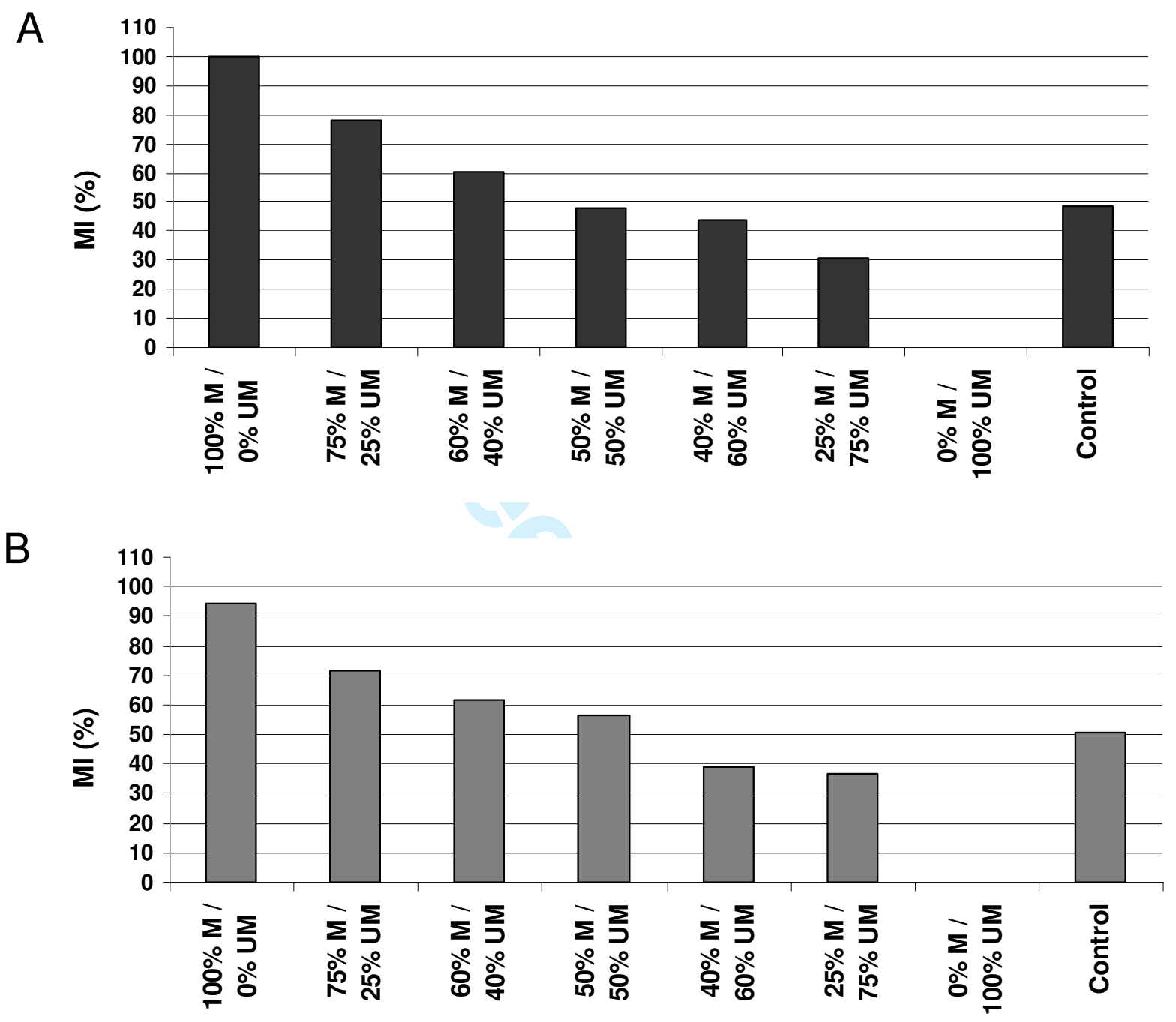

Figure S3: Concentration range of a mixture of EpiTech control DNAs (methylated and unmethylated) givinga theoretical MIs of $100 \%, 75 \%, 60 \%, 50 \%, 40 \%, 25 \%$ and $0 \%$, for both ICR1 (A) and ICR2 (B). The control DNA (pool of DNA from healthy subjects) was added as an internal control and showed a balance between the two alleles (50\%). M: methylated and UM: unmethylated. 
Figure S4:
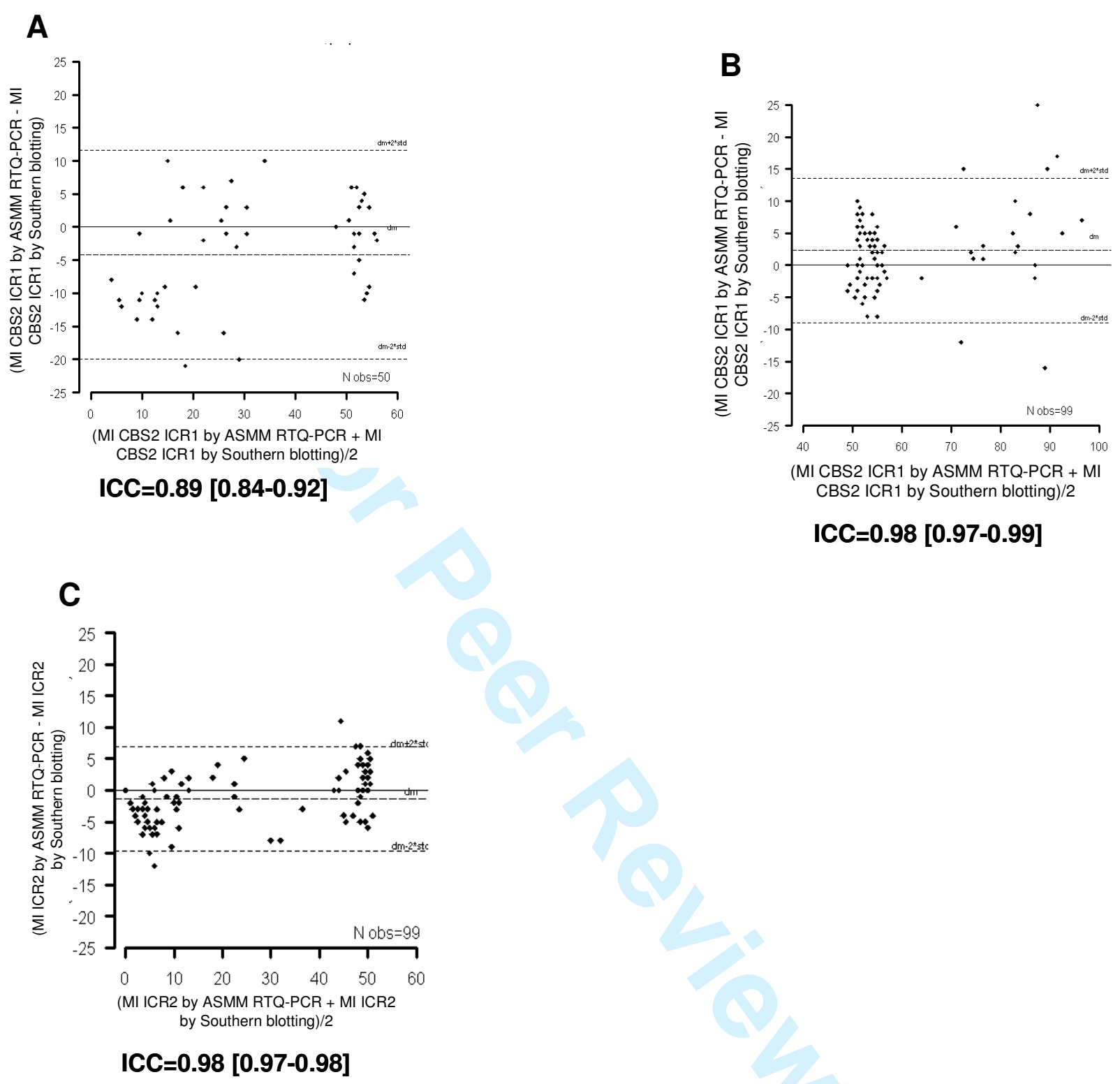

Figure S4: Bland and Altman's graphical representation of the intraclass correlation coefficient (ICC and its IC95\% by bootstrap). ASMM RTQ-PCR and Southern blotting agreement in the retrospective RSS (A) and BWS (B and C) cohorts for CBS2 ICR1 and ICR2 (difference of MI measurements against their mean value). 'Limits of agreement' is defined by the mean difference $(\mathrm{dm})$ and the standard deviation of the difference as $\mathrm{dm} \pm \mathrm{SD}$ for CBS2 ICR1 in both RSS (A) and BWS (B) cohorts and for ICR2 in the BWS cohort (C). 


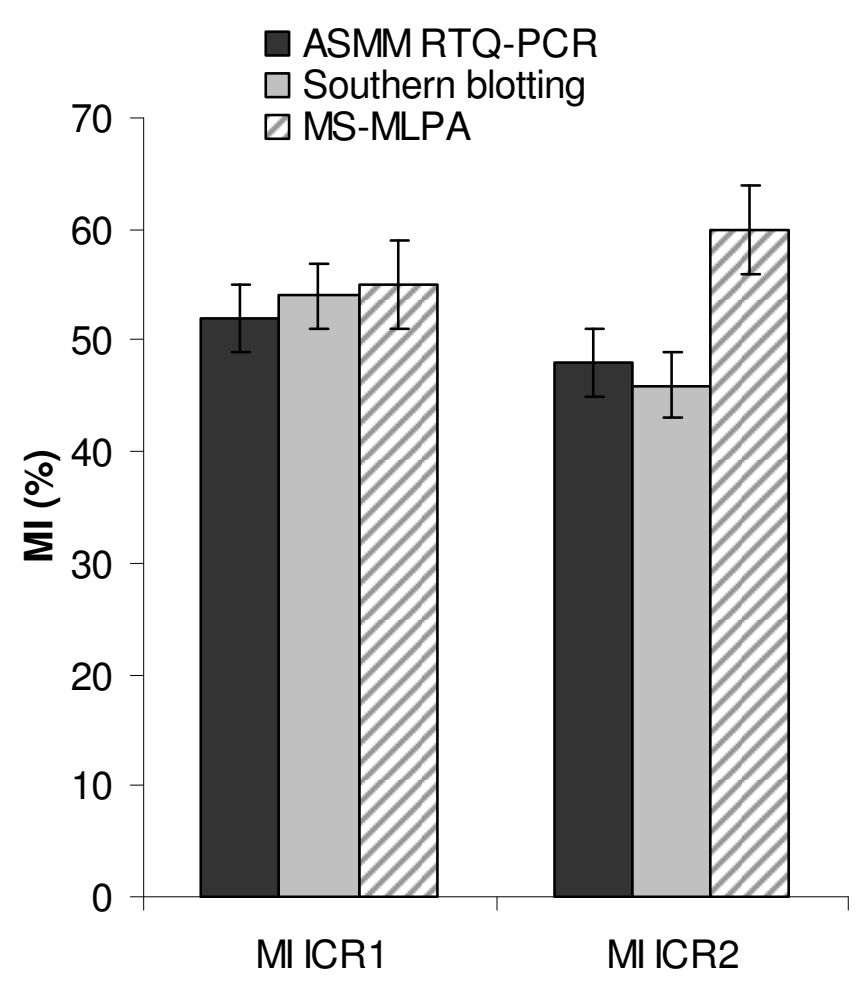

Figure S5: comparison between ICR1 and ICR2 MIs obtained with ASMM RTQ-PCR, Southern blotting and MS-MLPA. 
Tables

Table S1: Qualitative results for CBS2 ICR1 for the RSS population in the retrospective study

\begin{tabular}{cr|cc|c}
\hline ICR1 11p15 & & \multicolumn{2}{|c|}{$\begin{array}{c}\text { Southern blotting } \\
\text { conclusion }\end{array}$} & Total \\
& A & N & \\
\hline $\begin{array}{c}\text { ASMM } \\
\text { RTQ-PCR } \\
\text { Conclusion }\end{array}$ & A & 31 & 0 & 31 \\
\hline & Notal & 31 & 19 & 19 \\
\hline
\end{tabular}

Kappa coefficient $=\mathbf{1 . 0 0 0}$

$\mathrm{A}=$ abnormal DNA methylation (LOM), $\mathrm{N}=$ normal DNA methylation

Table S2: Qualitative results for CBS2 ICR1 for the BWS population in the retrospective study

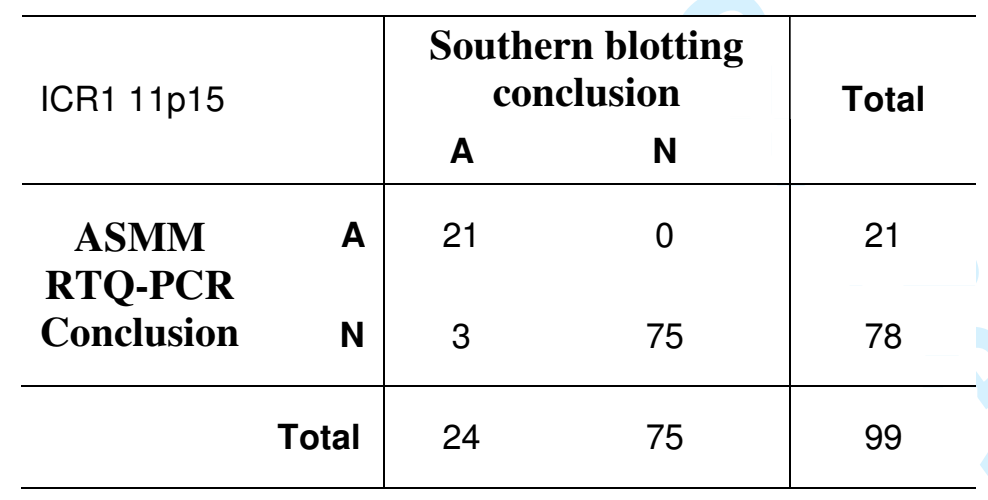

Kappa coefficient $\mathbf{=} \mathbf{0 . 9 1 3 8}$

$\mathrm{A}=$ abnormal DNA methylation (LOM or GOM), $\mathrm{N}=$ normal DNA methylation

Table S3: Qualitative results for ICR2 for the BWS population in the retrospective study

\begin{tabular}{cl|cc|c}
\hline \multirow{2}{*}{ ICR2 11p15 } & & \multicolumn{2}{|c|}{$\begin{array}{c}\text { Southern blotting } \\
\text { conclusion }\end{array}$} & Total \\
& & A & N & \\
\hline $\begin{array}{c}\text { ASMM } \\
\text { RTQ-PCR }\end{array}$ & A & 63 & 0 & 63 \\
Conclusion & N & 0 & 36 & 36 \\
\hline & Total & 63 & 36 & 99 \\
\hline
\end{tabular}

Kappa coefficient $\mathbf{=} \mathbf{1 . 0 0 0}$

$\mathrm{A}=$ abnormal DNA methylation (LOM), $\mathrm{N}=$ normal DNA methylation 
Table S4: Diagnostic established by ASMM RTQ-PCR, Southern blotting and MS-MLPA for a prospective population patients $(n=69)$. The row highlighted in yellow represent patients with MS-MLPA discordant MI and those highlighted in green represent the discordant MI obtained with either ASMM RTQ-PCR or Southern blotting. The discordant MIs are in bleu.

\begin{tabular}{|c|c|c|c|c|c|c|c|c|c|c|c|c|}
\hline \multirow[b]{3}{*}{$\begin{array}{l}\text { Patient } \\
\text { ID }\end{array}$} & \multicolumn{4}{|c|}{ ASMM RTQ-PCR } & \multicolumn{4}{|c|}{ Southern Blotting } & \multicolumn{4}{|c|}{ MS-MLPA } \\
\hline & \multicolumn{2}{|c|}{$52 \pm 3(46-58)$} & \multicolumn{2}{|c|}{$48 \pm 3(42-54)$} & \multicolumn{2}{|c|}{$54 \pm 3(48-60)$} & \multicolumn{2}{|c|}{$46 \pm 3(40-53)$} & \multicolumn{2}{|c|}{$55 \pm 3(49-61)$} & \multicolumn{2}{|c|}{$60 \pm 4(52-68)$} \\
\hline & $\begin{array}{c}\text { Ml } \\
\text { ICR1 }\end{array}$ & DIAG & $\begin{array}{c}\text { Ml } \\
\text { ICR2 }\end{array}$ & DIAG & $\begin{array}{c}\text { Ml } \\
\text { ICR1 }\end{array}$ & DIAG & $\begin{array}{c}\text { Ml } \\
\text { ICR2 }\end{array}$ & DIAG & $\begin{array}{c}\text { Ml } \\
\text { ICR1 }\end{array}$ & DIAG & $\begin{array}{c}\text { Ml } \\
\text { ICR2 }\end{array}$ & DIAG \\
\hline 582 & 49 & $\mathrm{~N}$ & 2 & LOM & 57 & $\mathrm{~N}$ & 3 & LOM & 55 & $\mathrm{~N}$ & 11 & LOM \\
\hline 641 & 50 & $\mathrm{~N}$ & 43 & $\mathrm{~N}$ & 57 & $\mathrm{~N}$ & 45 & $\mathrm{~N}$ & 54 & $\mathbf{N}$ & 58 & $\mathbf{N}$ \\
\hline 771 & 48 & $\mathrm{~N}$ & 38 & LOM & 53 & $\mathrm{~N}$ & 46 & $\mathrm{~N}$ & 55 & $\mathrm{~N}$ & 57 & $\mathrm{~N}$ \\
\hline 583 & 47 & $\mathrm{~N}$ & 44 & $\mathrm{~N}$ & 56 & $\mathrm{~N}$ & 45 & $\mathrm{~N}$ & 63 & GOM & 71 & GOM \\
\hline 627 & 51 & $\mathrm{~N}$ & 48 & $\mathrm{~N}$ & 55 & $\mathrm{~N}$ & 52 & $\mathrm{~N}$ & 53 & $\mathbf{N}$ & 56 & $\mathbf{N}$ \\
\hline 766 & 51 & $\mathrm{~N}$ & 49 & $\mathrm{~N}$ & 51 & $\mathrm{~N}$ & 46 & $\mathrm{~N}$ & 55 & $\mathrm{~N}$ & 55 & $\mathbf{N}$ \\
\hline 635 & 57 & $\mathrm{~N}$ & 52 & $\mathrm{~N}$ & 55 & $\mathrm{~N}$ & 53 & $\mathrm{~N}$ & 52 & $\mathbf{N}$ & 55 & $\mathrm{~N}$ \\
\hline 720 & 49 & $\mathrm{~N}$ & 50 & $\mathrm{~N}$ & 58 & $\mathrm{~N}$ & 49 & $\mathrm{~N}$ & 53 & $N$ & 54 & $\mathrm{~N}$ \\
\hline 642 & 51 & $\mathrm{~N}$ & 50 & $\mathrm{~N}$ & 56 & $\mathrm{~N}$ & 46 & $\mathrm{~N}$ & 53 & $\mathbf{N}$ & 54 & $\mathbf{N}$ \\
\hline 722 & 53 & $\mathrm{~N}$ & 1 & LOM & 58 & $\mathrm{~N}$ & 4 & LOM & 54 & $N$ & 11 & LOM \\
\hline 760 & 50 & $\mathrm{~N}$ & 43 & $\mathrm{~N}$ & 55 & $\mathrm{~N}$ & 49 & $\mathrm{~N}$ & 54 & $N$ & 57 & $\mathbf{N}$ \\
\hline 553 & 52 & $N$ & 45 & $\mathbf{N}$ & 59 & $\mathrm{~N}$ & 46 & $\mathrm{~N}$ & 65 & GOM & 66 & $\mathrm{~N}$ \\
\hline 554 & 47 & $\mathrm{~N}$ & 42 & $\mathrm{~N}$ & 56 & $\mathrm{~N}$ & 40 & $\mathrm{~N}$ & 53 & $\mathbf{N}$ & 52 & $N$ \\
\hline 651 & 54 & $\mathrm{~N}$ & 4 & LOM & 53 & $\mathrm{~N}$ & 7 & LOM & 54 & $\mathbf{N}$ & 11 & LOM \\
\hline 590 & 48 & $\mathrm{~N}$ & 44 & $\mathrm{~N}$ & 57 & $\mathrm{~N}$ & 48 & $N$ & 57 & $N$ & 56 & $\mathbf{N}$ \\
\hline 643 & 51 & $\mathrm{~N}$ & 48 & $\mathrm{~N}$ & 51 & $\mathrm{~N}$ & 50 & $\mathrm{~N}$ & 51 & $\mathbf{N}$ & 55 & $\mathbf{N}$ \\
\hline 652 & 49 & $\mathrm{~N}$ & 47 & $\mathrm{~N}$ & 49 & $\mathrm{~N}$ & 47 & $\mathrm{~N}$ & 51 & $\mathbf{N}$ & 57 & $N$ \\
\hline 653 & 47 & $\mathrm{~N}$ & 44 & $\mathrm{~N}$ & 50 & $\mathrm{~N}$ & 50 & $\mathrm{~N}$ & 55 & $N$ & 61 & $N$ \\
\hline 684 & 51 & $\mathrm{~N}$ & 44 & $\mathrm{~N}$ & 53 & $\mathrm{~N}$ & 50 & $\mathrm{~N}$ & 54 & $\mathbf{N}$ & 56 & $\mathbf{N}$ \\
\hline 637 & 53 & $\mathrm{~N}$ & 4 & LOM & 56 & $\mathrm{~N}$ & 5 & LOM & 54 & $N$ & 14 & LOM \\
\hline 721 & 48 & $\mathrm{~N}$ & 47 & $\mathrm{~N}$ & 59 & $\mathrm{~N}$ & 50 & $\mathrm{~N}$ & 55 & $N$ & 57 & $\mathbf{N}$ \\
\hline 685 & 52 & $\mathrm{~N}$ & 48 & $\mathrm{~N}$ & 49 & $\mathrm{~N}$ & 47 & $\mathrm{~N}$ & 53 & $\mathbf{N}$ & 58 & $\mathrm{~N}$ \\
\hline 398 & 30 & LOM & 44 & $\mathrm{~N}$ & 42 & LOM & 46 & $\mathrm{~N}$ & 40 & LOM & 59 & $\mathbf{N}$ \\
\hline 568 & 57 & $\mathrm{~N}$ & 45 & $\mathrm{~N}$ & 63 & GOM & 40 & $\mathrm{~N}$ & 58 & $\mathbf{N}$ & 51 & LOM \\
\hline 686 & 53 & $\mathrm{~N}$ & 46 & $\mathrm{~N}$ & 58 & $\mathrm{~N}$ & 46 & $\mathrm{~N}$ & 58 & $\mathbf{N}$ & 58 & $\mathbf{N}$ \\
\hline 765 & 55 & $\mathrm{~N}$ & 50 & $\mathrm{~N}$ & 54 & $\mathrm{~N}$ & 46 & $\mathrm{~N}$ & 52 & $\mathbf{N}$ & 56 & $\mathbf{N}$ \\
\hline 719 & 49 & $\mathrm{~N}$ & 47 & $\mathrm{~N}$ & 58 & $\mathrm{~N}$ & 50 & $\mathrm{~N}$ & 56 & $\mathbf{N}$ & 59 & $\mathbf{N}$ \\
\hline 759 & 52 & $\mathrm{~N}$ & 51 & $\mathrm{~N}$ & 57 & $\mathrm{~N}$ & 41 & $\mathrm{~N}$ & 52 & $\mathrm{~N}$ & 54 & $N$ \\
\hline 654 & 47 & $\mathrm{~N}$ & 49 & $\mathrm{~N}$ & 50 & $\mathrm{~N}$ & 47 & $\mathrm{~N}$ & 57 & $\mathbf{N}$ & 56 & $\mathbf{N}$ \\
\hline 645 & 51 & $\mathrm{~N}$ & 50 & $\mathrm{~N}$ & 51 & $\mathrm{~N}$ & 48 & $\mathrm{~N}$ & 53 & $\mathbf{N}$ & 54 & $\mathrm{~N}$ \\
\hline 646 & 53 & $\mathrm{~N}$ & 49 & $\mathrm{~N}$ & 53 & $\mathrm{~N}$ & 45 & $\mathrm{~N}$ & 53 & $N$ & 58 & $N$ \\
\hline 767 & 52 & $\mathrm{~N}$ & 50 & $\mathrm{~N}$ & 55 & $\mathrm{~N}$ & 46 & $\mathrm{~N}$ & 51 & $\mathbf{N}$ & 56 & $\mathbf{N}$ \\
\hline 585 & 47 & $\mathrm{~N}$ & 48 & $\mathrm{~N}$ & 58 & $\mathrm{~N}$ & 48 & $\mathrm{~N}$ & 64 & GOM & 67 & $N$ \\
\hline 594 & 55 & $\mathrm{~N}$ & 46 & $\mathrm{~N}$ & 58 & $\mathrm{~N}$ & 46 & $\mathrm{~N}$ & 55 & $\mathbf{N}$ & 58 & $\mathbf{N}$ \\
\hline 639 & 50 & $\mathrm{~N}$ & 44 & $\mathrm{~N}$ & 53 & $\mathrm{~N}$ & 44 & $\mathrm{~N}$ & 54 & $\mathrm{~N}$ & 57 & $\mathrm{~N}$ \\
\hline 655 & 52 & $N$ & 50 & $\mathrm{~N}$ & 46 & LOM & 45 & $\mathrm{~N}$ & 57 & $N$ & 60 & $N$ \\
\hline 586 & 53 & $\mathrm{~N}$ & 45 & $\mathrm{~N}$ & 59 & $\mathrm{~N}$ & 45 & $\mathrm{~N}$ & 57 & $\mathbf{N}$ & 70 & GOM \\
\hline 631 & 34 & LOM & 53 & $\mathrm{~N}$ & 39 & LOM & 50 & $\mathrm{~N}$ & 31 & LOM & 54 & $\mathrm{~N}$ \\
\hline
\end{tabular}




\begin{tabular}{|c|c|c|c|c|c|c|c|c|c|c|c|c|}
\hline 683 & 48 & $\mathrm{~N}$ & 46 & $\mathbf{N}$ & 57 & $\mathrm{~N}$ & 52 & $\mathrm{~N}$ & 50 & $\mathbf{N}$ & 53 & $\mathbf{N}$ \\
\hline 656 & 49 & $\mathrm{~N}$ & 3 & LOM & 48 & $\mathrm{~N}$ & 5 & LOM & 48 & LOM & 14 & LOM \\
\hline 596 & 51 & $\mathrm{~N}$ & 43 & $\mathrm{~N}$ & 49 & $\mathrm{~N}$ & 48 & $\mathrm{~N}$ & 58 & $\mathbf{N}$ & 56 & $\mathbf{N}$ \\
\hline 769 & 51 & $\mathrm{~N}$ & 45 & $\mathrm{~N}$ & 53 & $\mathrm{~N}$ & 43 & $\mathrm{~N}$ & 54 & $\mathbf{N}$ & 57 & $\mathbf{N}$ \\
\hline 657 & 49 & $\mathrm{~N}$ & 5 & LOM & 55 & $\mathrm{~N}$ & 10 & LOM & 53 & $\mathbf{N}$ & 15 & LOM \\
\hline 658 & 49 & $\mathrm{~N}$ & 1 & LOM & 52 & $\mathrm{~N}$ & 2 & LOM & 57 & $\mathbf{N}$ & 15 & LOM \\
\hline 681 & 56 & $N$ & 44 & $\mathrm{~N}$ & 57 & $\mathrm{~N}$ & 44 & $\mathrm{~N}$ & 58 & $\mathbf{N}$ & 58 & $\mathbf{N}$ \\
\hline 598 & 12 & LOM & 46 & $\mathrm{~N}$ & 32 & LOM & 43 & $\mathrm{~N}$ & 26 & LOM & 55 & $\mathrm{~N}$ \\
\hline 648 & 48 & $\mathrm{~N}$ & 50 & $\mathrm{~N}$ & 53 & $\mathrm{~N}$ & 46 & $\mathrm{~N}$ & 54 & $\mathbf{N}$ & 59 & $\mathrm{~N}$ \\
\hline 682 & 54 & $\mathrm{~N}$ & 48 & $\mathrm{~N}$ & 57 & $\mathrm{~N}$ & 47 & $\mathrm{~N}$ & 54 & $\mathbf{N}$ & 69 & GOM \\
\hline 649 & 55 & $\mathbf{N}$ & 46 & $\mathbf{N}$ & 52 & $\mathrm{~N}$ & 45 & $\mathrm{~N}$ & 54 & $\mathbf{N}$ & 54 & $\mathbf{N}$ \\
\hline 640 & 68 & GOM & 29 & LOM & 70 & GOM & 31 & LOM & 67 & GOM & 41 & LOM \\
\hline 659 & 46 & $\mathrm{~N}$ & 48 & $\mathrm{~N}$ & 50 & $\mathrm{~N}$ & 50 & $\mathrm{~N}$ & 53 & $\mathbf{N}$ & 56 & $\mathbf{N}$ \\
\hline 587 & 48 & $\mathrm{~N}$ & 45 & $\mathrm{~N}$ & 53 & $\mathrm{~N}$ & 46 & $\mathrm{~N}$ & 92 & GOM & 62 & $\mathrm{~N}$ \\
\hline 599 & 51 & $\mathrm{~N}$ & 43 & $\mathrm{~N}$ & 48 & $\mathrm{~N}$ & 45 & $\mathrm{~N}$ & 53 & $\mathbf{N}$ & 58 & $\mathbf{N}$ \\
\hline 588 & 46 & $\mathrm{~N}$ & 45 & $\mathrm{~N}$ & 51 & $\mathrm{~N}$ & 43 & $\mathrm{~N}$ & 49 & $\mathbf{N}$ & 55 & $\mathrm{~N}$ \\
\hline 724 & 46 & $\mathbf{N}$ & 47 & $N$ & 59 & $\mathrm{~N}$ & 50 & $\mathrm{~N}$ & 51 & $\mathbf{N}$ & 53 & $\mathrm{~N}$ \\
\hline 633 & 18 & LOM & 52 & $\mathrm{~N}$ & 32 & LOM & 52 & $\mathrm{~N}$ & 33 & LOM & 62 & $\mathrm{~N}$ \\
\hline 565 & 50 & $\mathrm{~N}$ & 52 & $\mathrm{~N}$ & 57 & $\mathrm{~N}$ & 45 & $\mathrm{~N}$ & 64 & GOM & 65 & $\mathbf{N}$ \\
\hline 545 & 100 & GOM & 9 & LOM & 85 & GOM & 15 & LOM & 95 & GOM & 20 & LOM \\
\hline 537 & 63 & GOM & 35 & LOM & 65 & GOM & 38 & LOM & 69 & GOM & 50 & LOM \\
\hline 539 & 62 & GOM & 33 & LOM & 79 & GOM & 14 & LOM & 88 & GOM & 25 & LOM \\
\hline 573 & 62 & GOM & 30 & LOM & 72 & GOM & 25 & LOM & 73 & GOM & 45 & LOM \\
\hline 577 & 64 & GOM & 29 & LOM & 69 & GOM & 31 & LOM & 68 & GOM & 43 & LOM \\
\hline 514 & 65 & GOM & 28 & LOM & 65 & GOM & 30 & LOM & 71 & GOM & 44 & LOM \\
\hline 348 & 0 & LOM & 2 & LOM & 8 & LOM & 3 & LOM & 10 & LOM & 16 & LOM \\
\hline 2160 & 71 & GOM & 24 & LOM & 74 & GOM & 24 & LOM & 81 & GOM & 33 & LOM \\
\hline 2383 & 61 & GOM & 54 & $\mathrm{~N}$ & ND & ND & ND & ND & 59 & $\mathrm{~N}$ & 62 & $\mathrm{~N}$ \\
\hline 396 & 32 & LOM & 37 & LOM & 32 & LOM & 53 & $\mathrm{~N}$ & 32 & LOM & 50 & LOM \\
\hline 1199 & 67 & GOM & 48 & $\mathrm{~N}$ & 83 & GOM & 50 & $\mathrm{~N}$ & 81 & GOM & 67 & $\mathrm{~N}$ \\
\hline 369 & 31 & LOM & ND & ND & 24 & LOM & 53 & $\mathbf{N}$ & 56 & $\mathbf{N}$ & 59 & $\mathbf{N}$ \\
\hline
\end{tabular}

LOM: Loss of methylation; GOM: gain of methylation; N: normal; ND: not determined; DIAG: diagnostic 